\title{
STEM Eğitimi Almış Öğretmenlerin STEM Öğretimi Hakkındaki Görüşleri*
}

\section{Sinan ÇINAR ${ }^{* *}$ ve Samet Yavuz TERZI****}

Öz: Bu çalışmanın amacı, STEM (Fen, Teknoloji, Mühendislik ve Matematik) hizmet içi eğitimi almış öğretmenlerin STEM eğitimi hakkında görüşlerini, uygulamalar sırasında yaşadıkları sorunları ve çözüm önerilerini ortaya çıkarmaktır. Çalışmada araştırma yöntemi olarak nitel araştırma yöntemi desenlerinden biri olan fenomenografik desen kullanılmıştır. Araştırmanın çalışma grubunu amaçlı örnekleme tekniklerinden biri olan uygun durum örnekleme tekniği kullanılarak STEM hizmet içi eğitim [HİE] kurslarına katılan 20 öğretmen oluşturmuştur. Araştırmada veri toplama aracı olarak yarı yapılandırılmış görüşme formu uygulanmış ve elde edilen verilerin analizi için betimsel ve içerik analizi kullanılmıştır. Elde edilen bulgular doğrultusunda, öğretmenlerin sınıflarında STEM eğitimi yaptıkları, STEM öğrenme ortamı oluşturmak için derslerine mühendislik ve teknoloji disiplinlerini entegre ettikleri, öğretim yöntemi olarak mühendislik tasarım süreci ve probleme dayalı öğrenme yöntemleri kullandıkları belirlenmiştir. Ayrıca öğretmenler STEM öğrenme ortamının öğrencilere disiplinler arası bir öğrenme ortamı yarattığı ve öğrencilerin yaratıcı düşünme ve problem çözme becerilerini geliştirdiği düşüncesine sahip oldukları bulunmuştur. Diğer taraftan öğretmenler ders öncesi STEM öğrenme ortamını tasarlarken malzeme temin edememe, STEM disiplinleri alan bilgi eksikliği ve öğretim programını yetiştirememe gibi kaygılara sahip oldukları, sınıflarında uygulamalarında de malzeme eksikliği, zamanın da yetiştirememe, gürültü ve STEM disiplinlerine ait bilgi eksikliği gibi engellerle karşılaştıkları tespit edilmiştir. Öğretmenlerin bu engelleri STEM eğitim uzmanlarıyla iş birliği yaparak alacakları öneriler ve sınıflarında STEM öğretimini uygulamaya devam ederek kazanacakları deneyimler sayesinde aşabileceği düşünülmektedir.

Anahtar Kelimeler: STEM Eğitimi, Öğretmen görüşleri, Nitel çalışma, Fenomenografik.

\section{Views of Teachers Taken STEM In-Service Training on STEM Education}

Abstract: The aim of this study is to reveal the views of teachers about STEM education, in particular the problems they experienced during the applications of STEM education and their solution suggestions. In this study, the phenomenographic pattern which is one of the qualitative research methods was used as the research method. The study group of the research consisted of 20 teachers who participated in STEM ISE [In-Service Training] courses and therefore the convenience sampling technique which is one of the purposive sampling

\footnotetext{
* Bu çalışma 2. Uluslararası Fen, Matematik, Girişimcilik ve Teknoloji Eğitimi Kongresi (E-Kongre)'inde sözlü bildiri olarak sunulmuştur.

**Dr. Öğr. Üyesi, Recep Tayyip Erdoğan Üniversitesi, Eğitim Fakültesi, Temel Eğitim Bölümü, Email:sinan.cinar@erdogan.edu.tr, Orcid No: 0000-0002-5208-8986.

*** Yüksek Lisans Öğrencisi, Recep Tayyip Erdoğan Üniversitesi, Sosyal Bilimler Enstitüsü, Email:sametyavuzterzi@hotmail.com, Orcid No: 0000-0002-4403-7759.
} 
techniques was used. Data was collected using a semi-structured interview form and the resulting data was performed by using descriptive and content analysis methods. It was determined that teachers who received STEM ISE education teach STEM-focused teaching, integrate engineering and technology disciplines into their lessons, particularly creating a STEM-focused teaching environment, and using the engineering design process and problembased learning methods. In addition, the teachers argued that the STEM teaching environment leads to an interdisciplinary learning environment for students and that both developed students' creative thinking and improve problem-solving skills. On the other hand, the teachers had various concerns, such as not being able to obtain materials, lack of knowledge on STEM disciplines and not being able to train the curriculum while designing STEM education. While applying STEM teaching in their classrooms, they face particular obstacles such as lack of materials, inability to deliver on time, noise, and lack of knowledge in STEM disciplines. It is assumed that teachers who had STEM ISE education would overcome such obstacles. Thanks to the recommendations they would be acknowledged in cooperation with STEM education experts and the experiences they would be gained by continuing to apply STEM education in their classes.

Keywords: STEM education, Teachers' views, Qualitative research, Phenomenographic.

\section{Giriş}

STEM eğitimi, öğrencilerin günlük yaşamdaki bir problem çerçevesinde mühendisliği ve teknolojiyi merkeze alıp fen ve matematik disiplinlerine ait bilgi ve becerilerini birbiriyle ilişkilendirerek yaratıcı çözümler üretmesi olarak tanımlanabilir (Aydeniz, 2017; Dugger, 2010). Ayrıca STEM'in hem eğitim (fen ve matematik) hem de iş dünyası (mühendislik, teknoloji, kariyer, ekonomik büyüme) olmak üzere iki boyutlu olduğu, eğitim ve iş dünyası arasında bir köprü görevi gördüğü de söylenebilir (TÜSİAD ve PwC, 2017). Bu kapsamda STEM eğitiminin hem bireysel açıdan öğrenciler için hem de işgücü açısından toplumlar için birçok potansiyele sahip olması politikacı ve sanayiciler tarafindan ekonomiyi canlandıracak bir katalizör olarak görülmüş ve eğitimciler açısından yaygınlaştırılması gereken bir eğitim politikası halini almıştır (Stohlmann, Moore ve Roehrig, 2012).

STEM eğitimine verilen bu önemle birlikte eğitim kurumlarında STEM'e dayalı öğretim programı hazırlama, öğretmen eğitimi ve profesyonel mesleki gelişim gibi çözülmesi gereken önemli sorunları da beraberinde getirmiştir (El-Deghaidy, Mansour, Alzaghibi ve Alhammad, 2017; Herro ve Quigley, 2017; Nadelson, vd., 2013). Bu duruma yönelik olarak ülkemizdeki eğitim ve iş dünyasında STEM eğitimine yön veren belge ve raporlar yayımlanmıştır; Türkiye Bilimsel ve Teknolojik Araştırma Kurumu’nun (TÜBİTAK) “'20112016 Bilim Teknoloji Kalkınma Planı’’ ve “2003-2023 Strateji Belgesi”, Türk Sanayicileri ve 
İş Adamları Derneği (TÜSİAD, 2015) tarafından yayımlanan “Fen, Teknoloji, Mühendislik, Matematik Alanında Eğitim Almış İşücüne Yönelik Talep ve Beklentiler Araştırma Raporu’” ve Milli Eğitim Bakanlığı (MEB, 2016) tarafından “STEM Eğitimi Raporu” vb.. Bu belge ve raporlar doğrultusunda Millî Eğitim Bakanlığı bir STEM Eylem Planı geliştirmiştir. Bu eylem planı doğrultusunda Yenilik ve Eğitim Teknolojileri Genel Müdürlüğü dünyada gerçekleşen çok sayıda STEM eğitimi ile ilgili projelerden haberdar olmak için 30 Avrupa ülkesinin katılım sağladığı "Scientix” projesine dâhil olmuştur (MEB, 2017). Tüm bu rapor ve çalışmalar doğrultusunda 2017 yılından itibaren STEM eğitimine dayalı öğretim programları geliştirme çalışmalarına başlamış, fen bilimleri öğretim programları, matematik öğretim programları ve teknoloji ve tasarım öğretim programları STEM eğitimi bağlamında tekrar revize edilmiştir. Ayrıca bu disiplinlerdeki öğretmenlerin ve diğer farklı disiplinlerdeki öğretmenlerin sınıflarında STEM eğitimine dayalı öğretim yapmaları için ‘’Okulöncesi Etkinlik Havuzu’’ web sitesi, “STEM Eğitimi Öğretmen El Kitabı', “'Kazanım Temelli STEM Etkinlikleri’, “Kodlama Kılavuzu” ve “Teknoloji ve Tasarım Öğretmenler için Kılavuz”' gibi çeşitli rehber öğretim materyalleri geliştirmiştir.

Ülkemizde STEM Eylem Planı'nın diğer bir boyutu ise öğretmenlerin STEM eğitimine karşı olumlu tutum sergilemeleri ve STEM ile ilgili bilgi ve beceri kazanmaları yönündeki hizmet-öncesi ve hizmet-içi faaliyetleri içermektedir (MEB, 2016). Bu yöndeki faaliyetlerin ise özellikle son yıllarda hem üniversiteler ve özel kurumlar tarafından hem de Milli Eğitim Müdürlüğü ARGE birimleri tarafindan dikkate alınarak yürütüldüğü görülmektedir (Aydeniz, 2017) Üniversitelerin bilimsel çalışmaları takip ettiği ve öğretim programlarını bu gelişmelere göre düzenlediği düşünüldüğünde ülkemizde birçok eğitim fakültesinde STEM yaklaşımları öğretim programı içerisinde yerini almaya başlamıştır (Çınar, Pırasa, Uzun ve Erenler, 2016). Öğretmen adaylarının dört senelik eğitim hayatı içerisinde uzun süreçli bir STEM eğitimi yer almaktadır. Örnek olarak fen bilgisi öğretmen adaylarına Fen Eğitimi 2, Disinpilinlerarası Fen Öğretimi, Bilimin Teknolojik Uygulamaları, Teknolojik Tasarım Projeleri gibi çeşitli dersler bünyesinde STEM eğitiminin fen bilgisi eğitimine entegrasyonuna yönelik bilgi ve beceri kazandırılmaya çalışılmaktadır. Ayrıca üniversitelerin bünyesindeki STEM merkezleri de bu gelişime çeşitli çalışmalar organize ederek önemli bir katkı sağlamaktadır (örneğin, Akaygun ve Aslan Tutak, 2016; Çınar, Pırasa, Uzun ve Erenler, 2016; Çınar, Pırasa ve Sadoğlu, 2016; Tarkın-Çelikkıran ve Aydın-Günbatar, 2017). Çınar, Pırasa, Uzun ve Erenler (2016) tarafından yapılan çalışmada mühendislik tasarım odaklı STEM eğitimine katılan fen bilimleri öğretmen adaylarının feni diğer STEM disiplinleri ile anlamlı bir şekilde ilişsilendirdiklerini bulmuştur. 
Akaygun ve Aslan Tutak (2016) tarafından yapılan çalışmada ise İşbirlikli FeTeMM Eğitim Modülü (IFFEM) eğitim programına katılan kimya ve matematik öğretmen adaylarının STEM anlayışlarında ve STEM farkındalıklarında olumlu yönde farklılıklar tespit etmiştir. Benzer şekilde, Tarkın-Çelikkıran ve Aydın-Günbatar (2017) çalışmalarında tasarım odaklı STEM eğitiminin öğretmen adaylarının disiplinler arası bakış açılarının gelişmesine katkı sağladığını bulmuştur. Fakat bu süreçte okullarda görevde olan öğretmenlerin de yeni reformları hayata hızlı bir şekilde geçirmesi gerekmektedir. Bu noktada MEM ARGE birimleri ve üniversitelerin STEM merkezleri iş birliği ile öğretmenlerin gelişimi için hizmet-içi gelişim kurslarının düzenlenmesi gerekmektedir. Ayrıca 2016 yılında yayımlanan STEM Eğitimi Raporu'nda bu birim ve merkezlerin STEM eğitim yaklaşımını sınıflarda etkin bir şekilde uygulaması ve yaygınlaştırması için öğretmen eğitimi ve hizmet-içi eğitim çalışmalarında önemli bir faktör olabileceği belirtilmiştir (MEB, 2016).

$\mathrm{Bu}$ bağlamda son yıllarda bu iş birliği içerisinde STEM eğitimine dayalı öğretmen yetiştirme programları eğitim sistemlerine eklenmiş ve ülke genelinde çeşitli hizmet-içi eğitim çalışmaları yürütülmüştür (örneğin, Altan ve Ercan, 2016; Timur, Timur ve Çetin, 2019; Tosmur-Bayazıt, Akaygün, Demir ve Aslan-Tutak, 2018). Altan ve Ercan'nın (2016) yaptığ çalışmada tasarım odaklı STEM mesleki gelişim programının öğretmenlerin STEM eğitimine ilişkin görüşlerini olumlu yönde etkilediğini ve öğretmenlerin tasarıma dayalı STEM etkinlik geliştirme becerilerinin gelişmesine olumlu katkı sağladığını tespit etmiştir. Tosmur-Bayazıt ve diğerleri (2018) ise mühendislik tasarım odaklı STEM etkinliklerin yer aldığı kursa katılan öğretmenlerin STEM etkinlikleri hakkında olumlu görüşe sahip olduklarını ve kursta yer alan STEM etkinliklerinin öğretmenlerin mühendislik becerilerinin gelişmesine önemli katkı sağladığını tespit etmişledir. Benzer olarak Timur ve diğerleri (2019), sorgulamaya dayalı STEM temelli etkinliklerin öğretmenlerin STEM eğitimine ilişkin görüşleri üzerinde olumlu bir etkisi olduğunu bulmuştur.

Hizmet öncesi ve hizmet-içi eğitim çalışmalarının yapılması öğretmenlerin sınıflarda STEM eğitimini başarılı bir şekilde uygulaması için oldukça önemlidir. Araştırmacılar eğitsel reformların başarılı olabilmesi için öğretmenlerin inanç, motivasyon ve farkındalıklarında çok önemli bir role sahip olduğunu da belirtilmektedir (Nathan, Atwood, Prevost, Phelps ve Tran, 2011). Margot ve Keller (2019) öğretmenlerin STEM eğitimine verdikleri değerin, STEM öğretimine dahil olma ve uygulama isteklerini etkilediğini ileri sürmektedir. Park, Byun, Sim, Han ve Baek (2016) STEM eğitimine değer veren öğretmenlerin sınıflarındaki öğretim deneyimi arttıkça, öğretmenlerin STEM öğretimine hazır olma düzeyinin de artacağını ve bir 
takım zorluk ve engellerin üstesinde gelme bilgi ve becerisini kazanacaklarını savunmaktadır. Ayrıca Park ve diğerleri (2016) STEM eğitimine değer veren öğretmenlerin sınıflarında öğrenci başarısını yaşamaya başladıklarında, STEM öğretimlerini uygulamaya devam etmek için önemli bir arzu duyacaklarını belirtmektedir. Diğer taraftan tüm öğretmenlere yönelik STEM HİE kurslarının düzenlenmesi ve tüm öğretmenlerin bu tür kurslara katılmasının, maliyet, zaman, kalifiye işgücü gibi çeşitli nedenlerden dolayı, oldukça zor bir durum olduğu söylenebilir. Bu durumda STEM eğitiminin okullarda başarılı olabilmesi için öğretmenlerin bu eğitimin gereğine ve önemine inandırılması yönünde çaba harcamalıdır (Gökçe ve Yıldırım, 2019). Bu çaba öğretmenlerin sınıflarında mevcut öğretim materyalleri rehberliğinde başarılı bir STEM öğretimi yapmasında önemli bir katkı sağlayabilir. Bu bağlamda sınıflarında STEM öğretimi uygulayan öğretmenlerin konuya bakış açılarının, STEM öğretiminde elde ettikleri öğrenme çıktılarının ve uygulamada karşılaştıkları engellerin ve önerilerinin bilinmesi oldukça önemlidir. Araştırmalar öğretmenlerin, STEM eğitimi hakkında uzman kişilerle oluşturduğu iş birliği kültürünün STEM programlarının uygulanabilirliğini artıracağına inandıklarını göstermektedir (Asghar, Ellington, Rice, Johnson ve Prime, 2012; Bruce-Davis vd., 2014; Herro ve Quigley 2017; Lehman, Kim ve Harris, 2014; Stohlmann vd., 2012; Wang, Moore, Roehrig ve Park, 2011). Sınıflarında STEM öğretimi yapan öğretmenlerin bilgi ve deneyimleri hakkında düşüncelerini paylaşması, bu bakımdan oldukça önemli olduğu düşünülmektedir. Ayrıca bu düşüncelerin mikro düzeyde STEM eğitimini uygulayan okul yöneticileri için ve makro düzeyde ise ülkenin eğitim politikalarını düzenleyenler için önemli açıklamalar ortaya koyacağı ve yol gösterici olacağı düşünülmektedir. Wang, Moore, Roehrig ve Park (2011)’a göre yüksek kalitede STEM entegrasyonu sağlayabilecek bir öğretim programı geliştirmek için öğretmenlerin düşüncelerinin ve sınıf uygulamalarının inceleyen çalışmaların yapılması gereken ilk işlem basamağıdır. Bu çalışma, STEM eğitimi almış öğretmenlerin STEM öğretimleri hakkında görüşlerini, uygulamalar sırasında yaşadıkları sorunları ve çözüm önerilerini belirlemeyi amaçlamaktadır.

\section{Yöntem}

\section{Araştırma Yöntemi}

$\mathrm{Bu}$ çalışma, 2019-2020 eğitim-öğretim y1lı güz döneminde Bayburt ilinde görev yapmakta olan STEM eğitimi almış öğretmenlerle yürütülmüştür. Çalışmada nitel araştırma yöntemi desenlerinden biri olan fenomenografik desen kullanılmıştır. Eğitim alanında yürütülen fenomenografik çalışmaların amacı, bireylerin bir fenomenin belirli bir yönünü 
tecrübe etmede, yorumlamada, anlamada veya kavramsallaştırmada ortaya koydukları farklı yolları tanımlamaktır (Çepni, 2007). Ayrıca bu tür çalışmalar, bireylerin edindiği bir olguyu, olası farklı kavramları sade bir mantıkla betimlemekte, birey ve tecrübeler arasındaki băg olarak görünen öğrenme ve öğretme durumları olarak açıklanmaktadır (Çepni, 2007). Bu kuramsal dayanak çerçevesinde araştırmada, öğretmenlerin STEM eğitimini tecrübe etme, yorumlama ve anlama yaşantılarına dayalı olarak STEM öğretimi hakkındaki görüşlerini ortaya çıkarmak için fenomenografik desen tercih edilmiştir.

\section{Çalışma Grubu}

Fenomenografik araştırmalarda veri kaynakları, araştırmanın odaklandığı olguyu yaşayan ve bu olguyu dişa vurabilecek veya yansitabilecek bireyler ya da gruplar olduğundan örnekleme tekniklerinden amaçlı örnekleme tekniği daha çok tercih edilmektedir (Yıldırım ve Şimşek, 2011). Bu araştırmada nitel araştırmanın yapısına ve araştırmanın amacına uygun olarak amaçlı örnekleme tekniklerinden biri olan uygun durum örneklemesi tercih edilmiştir. Bu kapsamda fenomenoloji deseninin amaçları doğrultusunda STEM konusunda eğitim almış öğretmenler katılımcı olarak tercih edilmiştir. Araştırmanın çalışma grubunda yer alan öğretmenler, Bayburt İl Milli Eğitim Müdürlüğü tarafından düzenlenen “Temel STEM Eğitimi” ve “İleri STEM Eğitimi”, hizmet içi eğitim kurslarına katılmışlardır. Beşer gün boyunca yürütülen bu kurslarda, katılımcı öğretmenler STEM öğretimi yapabilme bilgi ve becerisini kazanmak için hem teorik hem de pratik derslere katılmışlardır. Ayrıca iki kursta da öğretmenler, derslerinde STEM öğretimi yapabilmeleri için teorik ve uygulamalı ders planı geliştirme atölye çalışmalarına katılmışlardır (Bknz, Tablo 2, 3). Dolayısıyla uygun durum örneklemesi göz önünde bulundurularak, 2019-2020 eğitim-öğretim yılı güz döneminde yukarıda bahsedilen hizmet içi eğitim kurslarına katılmış 40 öğretmen arasından belirlenen 20 öğretmen çalışmaya gönüllü katılımcı olarak dahil edilmiştir. Diğer taraftan araştırmada etik prensipler gereğince katılımcı öğretmenlerin gerçek isimleri için Ö1, Ö2 ....Ö20 şeklinde kodlar kullanılmıştır. Çeşitli demografik değişkenlere göre katılımcı öğretmenlerin profilleri, Tablo 1'de sunulmuştur.

\section{Tablo 1}

Öğretmenlerin Demografik Değişkenlerine Göre Dă̆ılımı

\begin{tabular}{lccc}
\hline Öğretmenlerin Cinsiyet Dağılımı & $\mathrm{f}$ & $\%$ & Kod \\
\hline Kadın & 14 & 70 & \\
\hline Erkek & 6 & 30 & \\
\hline & Toplam & 20 & 100 \\
\hline Öğretmenlerin Branşları & $\mathrm{f}$ & $\%$ & \\
\hline Sınıf Öğretmeni & 6 & 30 & Ö1-Ö6 \\
\hline İlköğretim Matematik Öğretmeni & 5 & 25 & Ö7-Ö11 \\
\hline Fen Bilimleri Öğretmeni & 4 & 20 & Ö12-Ö15 \\
\hline
\end{tabular}




\begin{tabular}{|c|c|c|c|c|}
\hline Bilişim Teknolojileri Öğretmeni & & 2 & 10 & Ö16-Ö17 \\
\hline Teknoloji ve Tasarım Öğretmeni & & 2 & 10 & Ö18-Ö19 \\
\hline \multirow[t]{2}{*}{ Fizik Öğretmeni } & & 1 & 5 & Ö20 \\
\hline & Toplam & 20 & 100 & \\
\hline Öğretmenlerin Mesleki Deneyimleri & & $\mathrm{f}$ & $\%$ & \\
\hline $0-5 \mathrm{y} 11$ & & 5 & 25 & \\
\hline $6-10 \mathrm{y} 11$ & & 12 & 60 & \\
\hline \multirow[t]{2}{*}{$11-15$ y1l } & & 3 & 15 & \\
\hline & Toplam & 20 & 100 & \\
\hline
\end{tabular}

Tablo 1'de de görülebileceği gibi araştırmaya 14'ü kadın, 6'sı erkek olmak üzere toplam 20 öğretmen katılmıştır. Öğretmenlerin 6'sı sınıf öğretmeni, 5'i matematik öğretmeni, 4'ü fen bilimleri öğretmeni, 2'şer bilişim teknolojileri öğretmeni ile teknoloji ve tasarım öğretmeni ve 1'i de fizik öğretmenidir. Ayrıca 15 katılımcı öğretmenin mesleki deneyimi 6 yıldan fazla iken geri kalan 5 öğretmenin mesleki deneyimi ise 5 yıldan azdır.

\section{STEM Hizmet Iç̧i Eğitim Kursu}

Bayburt İl Milli Eğitim Müdürlüğü bünyesinde yürütülen“'Temel STEM Eğitimi Hizmet İçi Eğitim Kursu” ve "İleri STEM Eğitimi Hizmetiçi Eğitim Kursu”, programları 2019-2020 eğitim öğretim yılı bahar döneminde Bayburt öğretmen evi çok amaçlı toplantı salonunda yürütülmüştür. Her bir kurs beş gün (40 saat) boyunca sürmüştür. Kurs programları hakkında kapsamlı bilgi aşağıda verilmiştir.

\section{Temel STEM Eğitimi Hizmetiçi Eğitim Kursu}

Temel STEM Eğitimi Kurs Programı'nın amacı, fen, teknoloji, mühendislik ve matematik disiplinleri arasındaki ilişkiyi ve entegrasyonu vurgulayarak öğretmenlerin STEM yaklaşımına aşina olmalarını sağlamak, STEM disiplinleri arasındaki ilişkiyi derinlemesine kavratmak ve sınıflarında STEM eğitimine dayalı öğretimi kullanma yönünde pozitif bir inanç oluşturmak, bu konuda bilgi ve becerilerini geliştirmektir (Tablo 2).

\section{Tablo 2}

\section{Temel STEM Ĕ̈itimi Hizmetiçi Ĕ̈itim Kursu}

\begin{tabular}{|c|c|c|c|}
\hline Gün & Program aşamaları & İçerik & Saat \\
\hline \multirow[t]{3}{*}{ 1. Gün } & \multirow{3}{*}{ STEM Eğitimi } & STEM yaklaşımın doğası & 4 saat \\
\hline & & STEM yaklaşımının Fen bilgisi Eğitimine Entegrasyonu & \\
\hline & & $\begin{array}{l}\text { Mühendislik Tasarım Sürecini (MTS) Öğrenelim } \\
\text { STEM Da vinci Atölyesi (Eğimli Merdiven tasarımı) }\end{array}$ & 4 saat \\
\hline \multirow[t]{2}{*}{ 2. Gün } & \multirow[t]{2}{*}{$\begin{array}{l}\text { Sınıflarda } \\
\text { öğretimi }\end{array}$} & $\begin{array}{l}\text { STEM eğitiminde kullanılan yöntemler; } \\
\text { 5E, Proje tabanlı ögrenme, Probleme dayalı öğrenme } \\
\text { Ders planı geliştirme atölyesi }\end{array}$ & 4 saat \\
\hline & & STEM Statik Atölyesi (Köprü tasarımı) & 4 saat \\
\hline \multirow[t]{2}{*}{ 3. Gün } & \multirow{2}{*}{$\begin{array}{l}\text { STEM etkinlik } \\
\text { geliştirme-1 }\end{array}$} & Geliştirilen Modellerin derse Entegrasyonu & 4 saat \\
\hline & & $\begin{array}{l}\text { STEM Mekanik Atölyesi (Lunapark hızlı tren tasarımı) } \\
\text { Geliştirilen Modellerin derse Entegrasyonu }\end{array}$ & 4 saat \\
\hline 4. Gün & $\begin{array}{l}\text { STEM etkinlik } \\
\text { geliştirme-2 }\end{array}$ & $\begin{array}{l}\text { STEM Pnömatik Atölyesi (Aç1lır-kapanır kapı tasarımı) } \\
\text { Geliştirilen Modellerin derse Entegrasyonu }\end{array}$ & 4 saat \\
\hline
\end{tabular}




\begin{tabular}{llll}
\hline & & STEM Optik Atölyesi & 4 saat \\
& & Geliştirilen Modellerin derse Entegrasyonu & \\
\hline 5. Gün & STEM etkinlik & Özgün Mühendislik Tasarım Modeli & 4 saat \\
& geliştirme-3 & Geliştirilen Modellerin derse Entegrasyonu & 4 saat \\
\hline
\end{tabular}

\section{İleri STEM Eğitimi Hizmet içi Eğitim Kursu}

$\mathrm{Bu}$ kurs programının amacı, robotik teknolojinin STEM eğitimine nasıl entegre edileceğine yönelik tutum, bilgi ve becerileri kazandırmaktır. Kurs kapsamında öğretmenlere, STEM eğitiminde Robotik teknolojinin önemini anlama, Robotik eğitimin doğasını anlama, robotik teknoloji destekli STEM öğretimi yapma bilgi ve becerilerine sahip olma ve robotik teknolojinin sınıflarda uygulanabilirliği hakkında pozitif tutuma sahip olma şeklinde kazanımlar edindirmeye çalışılmıştır (Tablo 3).

\section{Tablo 3}

İleri STEM Ĕgitimi Hizmetiçi Ĕ̈itim Kursu

\begin{tabular}{|c|c|c|c|}
\hline Gün & Program aşamaları & İçerik & Saat \\
\hline \multirow{2}{*}{ 1. Gün } & STEM Eğitimde & $\begin{array}{l}\text { Kurs içeriği tanıtımı } \\
\text { STEM Eğitiminde Robotik uygulamalar, }\end{array}$ & 4 saat \\
\hline & $\begin{array}{l}\text { Mühendislik } \\
\text { Süreci }\end{array}$ & $\begin{array}{l}\text { Mühendislik Tasarım Süreci. } \\
\text { Mühendislik Tasarım Problemi: Köprü Tasarımı }\end{array}$ & 4 saat \\
\hline \multirow[b]{2}{*}{ 2. Gün } & \multirow[b]{2}{*}{ Kodlama-1 } & Mühendislik Tasarım Problemi: Roller Coaster Tasarımı & 4 saat \\
\hline & & $\begin{array}{l}\text { Robotik tasarım malzemelerini tanıma; } \\
\text { Atlı Karınca Tasarımı }\end{array}$ & 4 saat \\
\hline \multirow{2}{*}{ 3. Gün } & Kodlama -2 & $\begin{array}{l}\text { Digital ve Analog Sensör tanıtımı; } \\
\text { Sergi salonu Tasarımı }\end{array}$ & 4 saat \\
\hline & $\begin{array}{l}\text { Mühendislik } \\
\text { Projesi }\end{array}$ & Mühendislik tasarım problemi & 4 saat \\
\hline \multirow{2}{*}{ 4. Gün } & \multirow{2}{*}{$\begin{array}{l}\text { Robotiğin STEM eğitimine } \\
\text { Entegrasyonu-1 }\end{array}$} & Fotosentez & 4 saat \\
\hline & & Hiz ve İvme & 4 saat \\
\hline \multirow{2}{*}{ 5. Gün } & \multirow{2}{*}{$\begin{array}{l}\text { Robotiğin STEM eğitimine } \\
\text { Entegrasyonu-2 }\end{array}$} & Ders planı Geliştirme & 4saat \\
\hline & & Ders planı Geliştirme & 4 saat \\
\hline
\end{tabular}

Tablo 2 ve 3'de görüldüğü gibi yürütülen HİE kurslarında katılımcı öğretmenlerin STEM eğitimini derslerine entegre edebilmeleri için gerekli olan bilgi ve beceriler, hem teorik hem de uygulamalı derslerle kazandırılmaya çalışılmıştır. Ayrıca öğretmenlerin derslerinde STEM eğitimine dayalı öğretim yapabilmeleri için ders planı geliştirmeye yönelik teorik ve uygulamalı derslerin yer aldığı dikkat çekmektedir.

\section{Veri Toplama Aracı}

Çalışmada, araştırmacı tarafından geliştirilen yarı yapılandırılmış görüşme formu kullanılmıştır. Form oluşturulurken araştırmanın amaçları doğrultusunda alanyazın taranmış ve STEM eğitimine karşı öğretmenlerin görüşlerini belirlemeye yönelik maddeler belirlenmiştir. Açık uçlu sorulardan oluşan formda öğretmenlerden STEM öğretim şekilleri, sınıflarında STEM öğretimden elde ettikleri öğrenme çıktıları ve STEM öğretimin sınıflarda 
uygulanabilirliğine ilişkin görüş ve önerilerini nedenleri ile açıklanması istenmiştir. Başlangıçta 12 soru olarak hazırlanan mülakat soruları için çalışma grubunda yer almayan, ancak STEM eğitimi almış iki öğretmenle pilot çalışması yapılmış ve görüşme soruları dokuz soruya düşürülmüştür. Dokuz sorudan oluşan mülakat aracının kapsam ve biçim açısından yeterli olup olmadığının kontrol edilmesi için STEM alanında çalışmaları bulunan bir uzman ile Türk Dili uzmanının görüşleri alınmış ve alınan dönütler sonucunda gerekli düzeltmeler yapılmış ve mülakat aracına son hali verilmiştir. Bununla birlikte bu aşamadan sonra tekrar bir pilot çalışması yapılmamıştır.

\section{Verilerin Toplanması}

Araştırmacı tarafından geliştirilen dokuz soruluk yarı yapılandırılmış görüşme formu, Millî Eğitim Bakanlığı'na bağlı okullarda görev yapmakta olan ve STEM eğitimi almış 20 öğretmene uygulanmıştır. Katılımcı öğretmenlerle görüşmeler uygun tarih ve saatler belirlenerek Bayburt STEM Merkezi’nde yüz yüze yapılmıştır. Her bir öğretmen ile yaklaşık bir saat süren görüşme yapılmış olup süreç boyunca öğretmenlere herhangi bir yönlendirme ve etkileme yapılmamış, kendilerini rahat hissedebilecekleri bir ortam oluşturulmuştur. Bu aşama, on gün devam etmiştir. Görüşmeler katılımcı öğretmenlerin onayı alınarak ses kayıt cihazı ile kayıt altına alınmıştır.

\section{Verilerin Analizi}

Fenomenografik araştırmalarda veri analizi, yaşantıları ve anlamları ortaya çıkarmaya yöneliktir. Bu amaçla yapılan içerik analizinde verinin kavramsallaştırılması ve olguyu tanımlayabilecek temaların ortaya konulması çabası vardır. Sonuçlar betimsel bir anlatımla okuyucuya sunulur. Bunun yanında ortaya çıkan temalar ve örüntüler çerçevesinde elde edilen bulgular açıklanır ve yorumlanır (Yıldırım ve Şimşek, 2011). Nitel çözümlemede ilk ve temel işlem, verilerin içeriklerini keşfetmeye yönelik çözümleme açısından geçerli bir kodlamanın yapılmasıdır (Yıldırım ve Şimşek, 2011).

Katılımcı öğretmenlere görüşmelerin yaklaşık olarak 1'er saat süreceği ve görüşmenin istedikleri yerinde görüşmeyi bitirebilecekleri ya da ara verebilecekleri bildirilmiştir. Görüşme bitiminde görüşmelerin transkripsiyonu araştırmacılar tarafindan yapıldıktan sonra öğretmenlere gönderilerek katılımcı teyidi alınmıştır. Yıldırım ve Şimşek’in (2011) açıklamalarından hareketle veri toplama aracının açık uçlu sorulardan oluşması sebebiyle elde edilen verilerin değerlendirilmesinde içerik analizi yapılarak açık kodlama yöntemine başvurulmuştur. Öğretmenlerin onayı ile verdikleri cevaplar, ses kayıt cihazı ile kayıt altına alınmış, daha sonra var olan ses kayıtları araştırmacılar tarafından dikte edilerek bilgisayara 
aktarılmış, oluşan metinler birkaç kez okunup kodlamalar geliştirilmiştir. Kodlar toplanarak ortak yönleri bulunmuş, araştırma bulgularının ana hatlarını meydan getirecek temalar ortaya çıkarılmıştır (Tablo 4). Temalar kapsadığı kodlar ile ilişkili bir biçimde açıklanarak yorumlanmış ve çalışmanın amacı doğrultusunda sonuçlar dayandırılarak ileri sürülmeye çalışılmıştır. Ayrıca araştırmacı, temaları desteklemek amacıyla görüşme metinlerinden alıntıları tablo altında vermiştir (Tablo 4).

\section{Tablo 4}

Veri Analizi Sonucunda Oluşturulan Temaların Kategorilere Göre Dă̆glımı

\begin{tabular}{ll}
\hline Kategoriler & \multicolumn{1}{c}{ Temalar } \\
\hline \multirow{3}{*}{ STEM Öğretim Şekilleri } & Öğretime Entegre Edilen STEM Disiplinleri \\
\cline { 2 - 2 } STEM Öğretiminde Öğrenci & STEM Öğretiminde Kullanılan Yöntem ve Teknikler \\
\cline { 2 - 2 } & STEM Öğretiminin Sağladığı Öğrenme Ortamı \\
\cline { 2 - 2 } & STEM Öğretimin Öğrenci Üzerine Olumlu Etkisi \\
\hline \multirow{3}{*}{ STEM Öğretiminde Öğretmen } & STEM Öğgretimin Öğrenci Açısından Olumsuzluğu Sınıfta Kullanma Sıklı̆̆ı \\
\cline { 2 - 2 } & STEM Öğretiminde Öğretmenlerin Kaygıları \\
\cline { 2 - 2 } & Öğretmelerin STEM Öğretimi Yaparken Yaşadıkları Zorluklar \\
\cline { 2 - 2 } & STEM Öğretimi İçin Öğretmenlere Öneriler \\
\hline
\end{tabular}

\section{Geçerlik ve Güvenirliğin Să̆lanması}

Çalışmada elde edilen verilerinin geçerlik ve güvenirliğini artırmak amacıyla katılımcı teyidinin alınmasına gerek görülmüştür. Ayrıca geçerliği sağlamak için fazla betimlemelere yer verilmiştir. Durum tanımlanırken veya bir tema hakkında bilgi verilirken detaylar da aktarılmıştır. $\mathrm{Bu}$ betimlemeler, okuyucunun sonuçların diğer ortamlara aktarılıp aktarılamayacağına karar vermesine yardımcı olur. Çoklu kodlayıcı kullanılması ve kodlayıcılar arasında uyumun olması güvenirliği arttıran bir husustur (Yıldırım ve Şimşek, 2011). Araştırma kapsamında iki araştırmacı tarafından kodlamalar farklı ortamlarda yapılmıştır. Miles ve Hubermann'ın (1994) uyuşum yüzdesi hesaplanmış ve değer \%93 bulunmuştur. Uyum olmayan \%7'lik dilim iki araştırmacı tarafından tekrar incelenmiş, inceleme sonucunda 61 koddan 57'si çalışmaya eklenmiş ve dört kod araştırma dışına çıkarılmıştır. $\mathrm{Bu}$ işlemin ardından araştırmacılar tarafından kodlar yeniden düzenlenerek veriler gruplandırılmış ve temalar oluşturulmuştur. Bazı sorularda öğretmenlerin bir soru içerisinde belirtmiş oldukları düşünceler birden fazla kodun altında işlenmiştir. Ayrıca temalarla ilgili olarak görüşme boyunca sorulan sorulara öğretmenlerin vermiş olduğu cevaplardan örnek bir ifadeye de yer verilmiştir. Araştırmacı, analizlerden elde edilen bulgulara ve sonuçlara baktıktan sonra gerekli bilgiye ulaştıklarını düşünerek öğretmenlerle ek olarak başka bir mülakat görüşmesi yapmaya gerek olmadığına karar vermiştir. 


\section{Bulgular}

Bulgular kategoriler altında tema sırasına göre ayrıntılı bir şekilde ayrı ayrı incelenmiştir.

\section{Öğretime Entegre Edilen STEM Disiplinleri}

Öğretmenlerin derslerinde STEM öğretimi oluşturmada derslerine entegre ettiği disiplin veya disiplinler ile ilgili görüşleri ele alındığında, öğretmen düşüncelerinin dört kodda toplandığı ve daha çok mühendislik ve teknolojide yı̆̆ılma olduğu tespit edilmiştir.

\section{Tablo 5}

"STEM disiplinlerinden daha çok hangi disiplin veya disiplinleri ögretiminize entegre ediyorsunuz?' Sorusuna İlişkin Ö̈̆retmen Görüşleri.

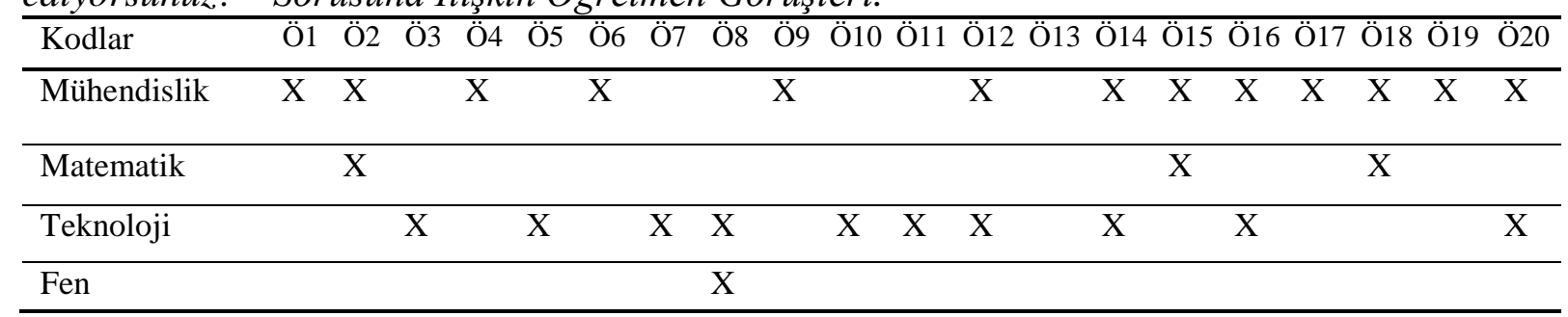

Tablo 5’de görüldüğg̈ öğretmenler STEM öğretimlerine kendi disiplini dışında tek bir STEM disiplini entegre ettiklerini, iki disiplin entegre eden öğretmen sayısının az olduğu ve üç disiplin entegre eden öğretmenin ise olmadığı görülmektedir. Öğretmenlerin büyük bir çoğunluğu derslerine mühendislik disiplinini ve teknoloji disiplinlerini entegre ettiklerini belirtmişlerdir. Derse mühendislik entegrasyonu ile ilgili olarak Ö5 “Fen bilimleri derslerinde MTS yöntemini kullanarak etkinlikler geliştiriyorum, ögrencilerim basit malzemeler ile çok güzel yaratıcı modeller inşa ediyor... Depremde yıklmayan ev modeli, ses yalıtımlı oda gibi”' ve Ö17 ise “Bileşim öğretiminde kodlama ögrretirken MTS yöntemini kullanıyoruz. Öğrencilere kodlama yani akış şeması oluşturmayı ögrettikten sonra bir problemin çözümüne yönelik olarak akış şemaları yazmaları ve bu kodu çalıştırmalarını istiyorum...'’şeklinde düşüncelerini belirtirmiştir. Her iki disiplini de entegre ettiğini belirten Ö20 “Fizik dersi STEM yaklaşımı için çok uygun bir ders, derste MTS yöntemini kullanıyorum... Problem durumunu çözüm araştırırken internet ve bilgisayar yani teknoloji kullanıyoruz ... Etkinliklerde matematik de var fakat sadece işlem olarak...” ş̧eklinde, Ö8 “"Matematik dersinde sadece geometri konularında STEM ögrretimi yapabiliyorum, geometri konularına mühendislik tasarım yöntemi kullanıyorum... Pisagor konusunda ögrencilerime Pisagor teoremini kullandırarak yangın merdiveni tasarlattım. Öğrenciler çok güzel tasarımlar yaptı..." şeklinde düşüncelerini ifade etmişlerdir. 


\section{STEM Öğretimde Kullanılan Yöntem ve Teknikler}

Öğretmenlerin derslerinde STEM öğretimi yaparken kullandıkları yöntem ve teknikler ile ilgili görüşleri ele alındığında, öğretmen düşüncelerinin beş kodda toplandığı ve daha çok MTS yöntemi, probleme dayalı öğrenme ve işbirlikçi öğretim yöntemlerin de yı̆̆ılma olduğu tespit edilmiştir.

\section{Tablo 6}

“STEM öğretimi yaparken hangi yöntem ve teknikleri kullanıyorsunuz?” Sorusuna İlişkin Öğretmen Görüşleri.

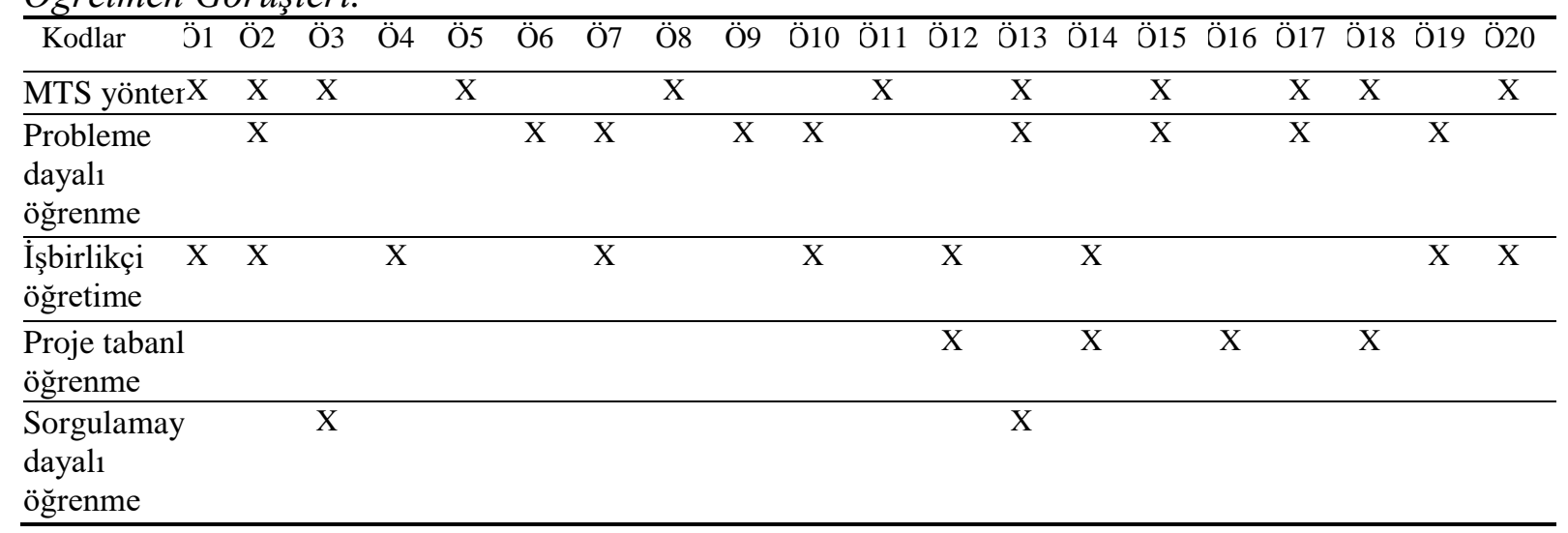

Tablo 6 incelediğinde öğretmenlerin STEM öğretim ortamı tasarlamada birden fazla öğretim yöntemini işaret ettiği görülmektedir. Öğretmenlerin çoğunluğu MTS yöntemi kullandıkları belirlenmiştir. Örnek olarak; Ö3 “ 'STEM odaklı öğretim yapmak için genellikle MTS yöntemini kullanıyorum, öğrencilerim MTS başmaklarında ezberlediler... Öğrencilerim tasarım sürecinde grup olarak çalışıyorlar ve iş bölümü yapıyorlar' ş̧eklinde düşüncelerini ifade etmiştir. Bir kısım öğretmen probleme dayalı öğretim yöntemini kullandıkları belirtmiştir. $\mathrm{Bu}$ durumla ilgili olarak Ö19 “Tasarım dersinde öğrencilerime sınıftaki veya günlük yaşamda karşılaşılan veya karşılaşılması muhtemel bir problemi veriyorum... Ayrıca problemle ilgili çözüm için kriterlerde veriyorum. Onlarda grup olarak çözüm için ürettikleri tasarımlarını bu kriterlere göre geliştiriyorlar' ' ifadesinde bulunmuştur. Başka bir kısım proje tabanlı öğretim yöntemini daha çok tercih ettiklerini belirtmişlerdir. Örnek olarak Ö18 kodlu öğretmen “Konuyu anlattıktan sonra öğrencilerin konuyu günlük hayata adapte etmeleri için onları konuyla ilgili günlük yaşam problemlerle karşı karşıya bırakıyorum, onlarda grup olarak birtakım projeler üretiyorlar ve sunuyorlar', şeklinde belirtmişlerdir.

\section{STEM Ö̆̆retiminde Ö̆̆renci}

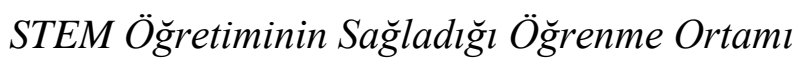


Öğretmenlerin STEM öğretimi öğrencilere nasıl bir öğrenme ortamı sağlarla ilgili görüşleri ele alındığında, öğretmen düşüncelerinin altı kodda toplandığg ve daha çok problemçözme, yaratıcı öğrenme ve disiplinler arası öğrenme ortamlarında yığgldı̆̆ı tespit edilmiştir.

\section{Tablo 7}

“STEM ögrretim öğrencilere ne tür bir öğrenme ortamı sağlar?” Sorusuna İlişkin Öğretmen Görüşleri.

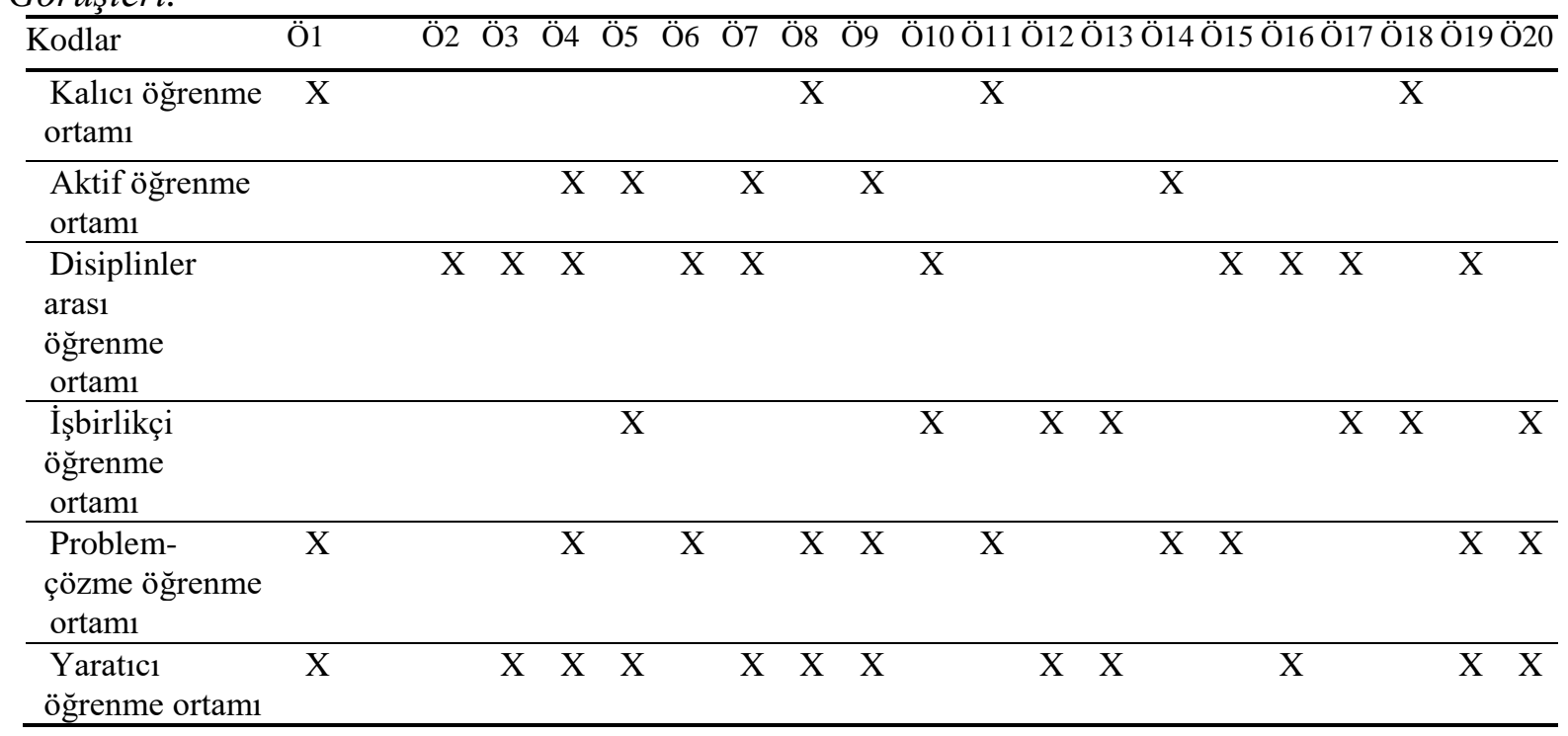

Tablo 7 incelendiğinde katılımcıların çoğunluğu çok yönlü cevaplar vermiştir. Tüm katılımcılar birden fazla cevap vermiştir. Ö1 kodlu katılımc1, “Öğrenciler günlük hayat problemlerine bilimsel bilgiyi kullanarak çözüm ürettikleri için öğrenmede kalıcılık sağlanmaktadır.” cevabını vermiştir. Ö15 kodlu katılımcı ise en geniş kapsamlı cevabı “Grup çalışması, MTS yöntemi kullanarak geliştirilen STEM etkinliklerinde her öğrenci sürece aktif olmaktadır. Matematik ve fen disiplinleri mühendislik becerileri kullanılarak teknolojinin kullanımıyla öğrencilerde disiplinler arası bir yapıya bürünmektedir. Çoklu disiplinlerin bir bütün içerisinde ders planına yansıması ve bunun ögrencinin kendi problemlerine çözüm olarak kullanılması öğrenmede kalıcılı̆̆ı sağlamaktadır.” şeklinde vermiştir. Ö18 verdiği cevapta “Öğrenciler grup çalışması yaptıkları için işbirlikçi öğrenme gerçekleşmektedir. Ayrıca farklı bakış açıları ve çözüm yolları ürettikleri için dersi daha kolay öğrenmekte ve bilgiyi pratiğe dökerek özümsemekte ve en önemlisi yaratıcılıkları gelişmektedirler.” diyerek görüşünü belirtmektedir.

\section{STEM Öğretiminin Öğrenci Üzerine Olumlu Etkisi}

Katılımcı öğretmenlerin sınıfta oluşturdukları STEM öğrenme ortamının öğrencilerin hangi tür bilgi ve becerilerini gelişmesini sağlayacağı yönündeki düşüncelerine bakıldığında, düşüncelerinin dokuz kod altında toplandığı ve öğretmenlerin büyük bir çoğunluğunun STEM 
öğretimin öğrencilerin 21. Yy becerileri, yaratıcı düşünme becerileri ve problem çözme becerilerini geliştireceği yönün de görüşlere sahip olduğu tespit edilmiştir.

\section{Tablo 8}

“STEM ögrretimi ögrrencilerin ne tür bilgi ve becerilerinin gelişmesini sağlar?” Sorusuna İlişkin Öğretmen Görüşleri.

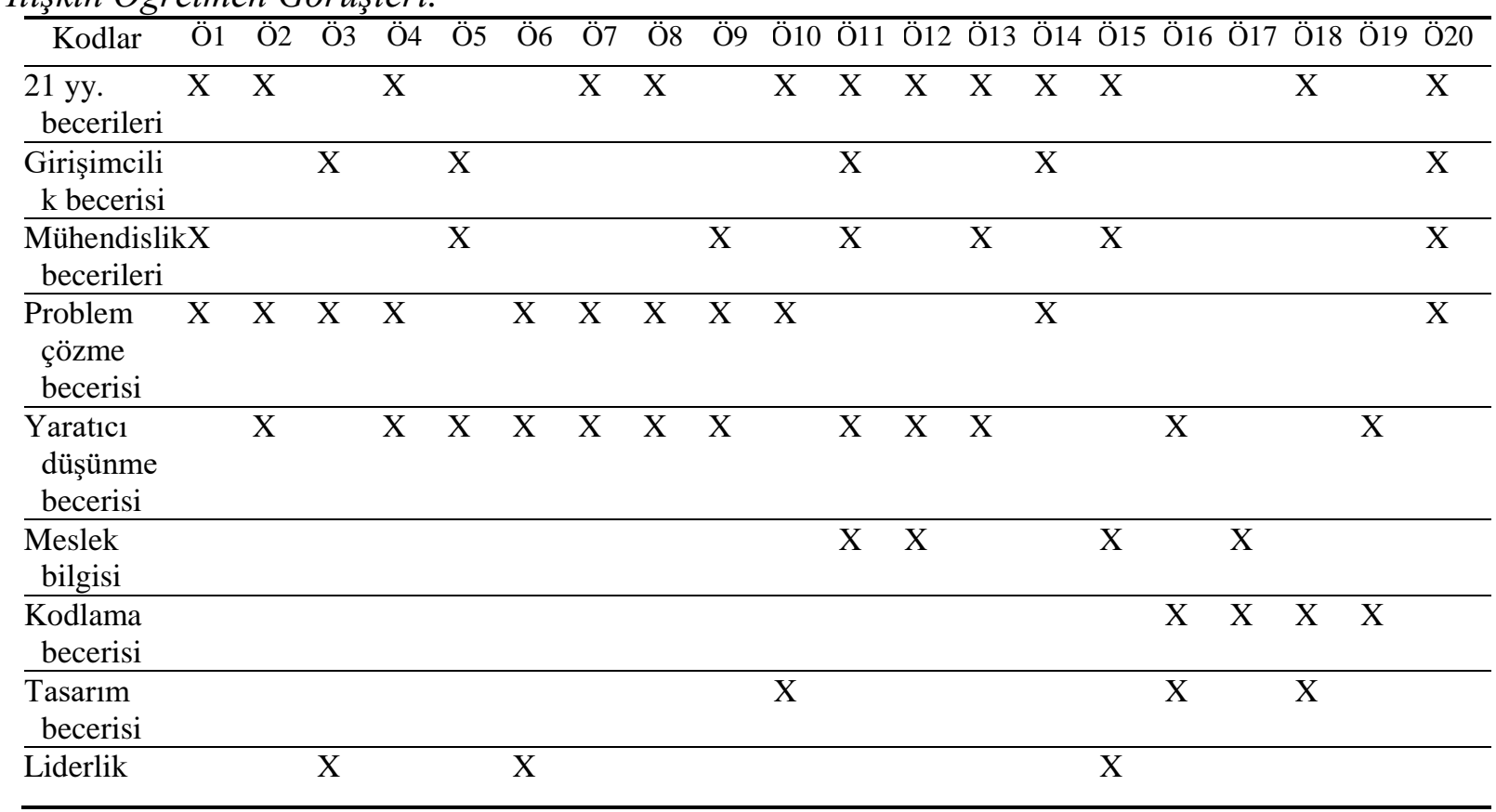

Tablo 8 incelendiğinde katılımcılar STEM öğretiminin öğrencilerin 21 yy, yaratıcı düşünme, problem çözme, mühendislik, girişimcilik, kodlama, tasarım ve liderlik becerilerini geliştirdiğini ve meslek bilgisi ve teknoloji bilgisi kazandırdığı düşünmektedir. Örnek olarak, Ö13 “Öğrencilerin çă̆ın gerektirdiği yaratıcılık, eleştirel düşünme ve problem çözme, girişimcilik, grupla çalışma ve liderlik gibi 21 yy. becerilerine sahip ve özgüven sahibi bireyler olarak yetişmelerine katkı sağlamaktadır." şeklinde sıralamaktadır. Ö20 ise "STEM eğitimi, ögrencilerin 21 yy. becerilerinin gelişimine katkı sağlarken çă̆ın getirdiği teknolojik bilgi ve becerilere adapte olmasını sağlamaktadır. Ayrıca müfredat içerisinde akademik bilgiye boğulan ögrrencinin etkinlikler aracılı̆̆lyla mühendislik becerilerinin gelişimini sağlamaktadır.” şeklinde görüş bildirmektedir. Ö11 “STEM eğitimi içerisinde yer alan MTS etkinliklerinin ögrencilerin mühendislik becerilerini geliştirir, farkl STEM mesleklerini tanımasını sağlar, yaratıcı çözümler üretmelerini sağlayarak yaratıcı ve problem çözme becerilerini geliştirir..." ifadesin de bulunmuştur.

\section{STEM Öğretiminin Öğrenci Açısından Olumsuzluğu}

Öğretmenlerin STEM öğretiminde öğrencilerin ne tür olumsuzluklar yaşadığına yönelik düşüncelerine bakıldığında, düşüncelerinin beş kod altında toplandığı ve en fazla 
sıklığa olumsuzluk yok kodunun sahip olduğu görülürken bu kodu sıklık olarak pasif kalma, yetiştirememe kaygısı ve erken vazgeçme kodlarının takip ettiği görülmektedir.

\section{Tablo 9}

“STEM öğretiminde öğrenciler ne tür olumsuzluk yaşamaktadır?” Sorusuna İlişkin Öğretmen Görüşleri.

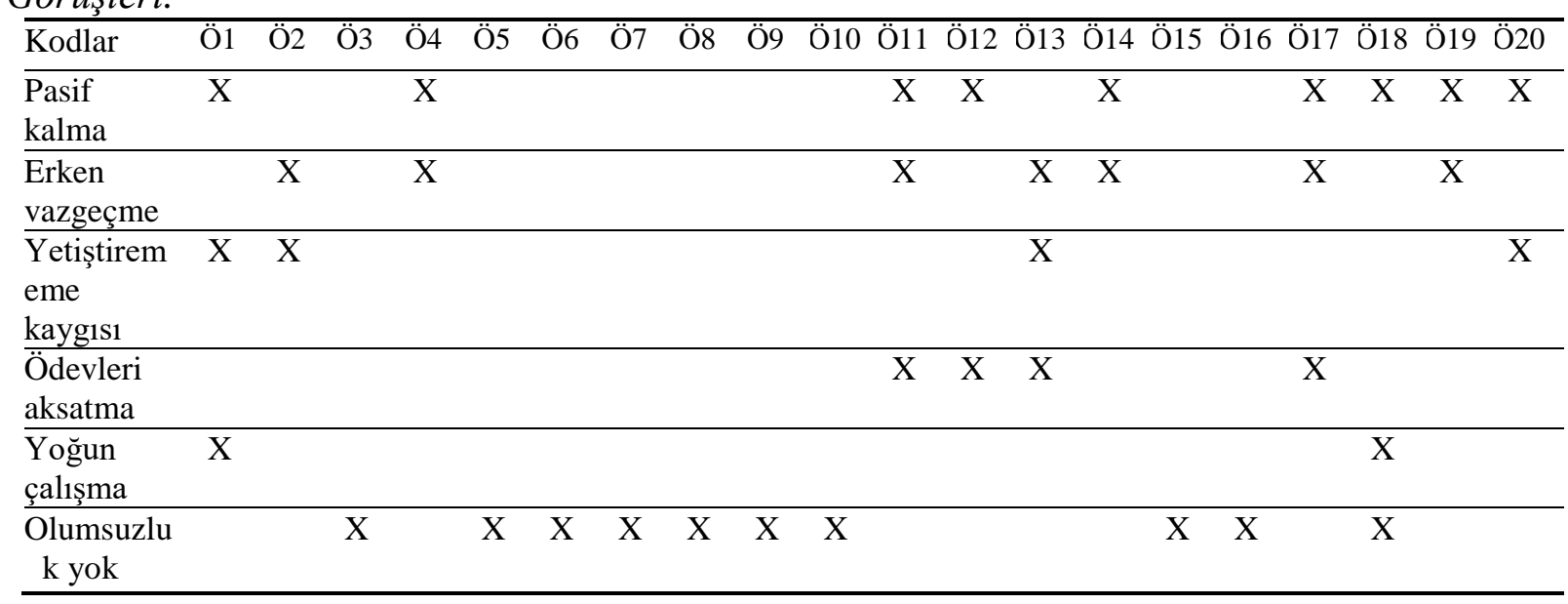

Tablo 9 incelendiğinde katılımcıların yarısı STEM öğretimin öğrencilere bir olumsuzluk yaşatmadığını ifade ederken diğer yarısı öğrenciler üzerinde bazı olumsuzlukları meydana getirdiğini belirtmişlerdir. Örnek olarak, Ö7 verdiği cevapta “Grup çalışması içerisinde bazı ögrencilerin diğer öğrencilere pasif kaldı̆̆ı, etkinliklerde aktif olmadı̆̆ sadece sırasında oturduğu gözlemledim..." şeklinde bir açıklama yaparak pasiflik kalma kaynaklı bir olumsuzluktan bahsetmektedir. Ö17 ise “Bazı öğrenciler, diğer öğrencilerden daha geç etkinlikleri tamamladığından dolayı sonraki etkinlikleri de yetiştirememe kaygısından dolayı katılmada ve yapma isteksizlik göstermektedirler." açıklamasında yetiştirememe kaygısının ortaya çıkmasına vurgu yapmıştır. Ö10 düşüncesinde "Öğrenciler, etkinlik içerisinde bir şeyleri yapamama, takamama gibi olumsuzluklar yaşadıklarında etkinlikleri yarıda bırakıyorlar. Onun için STEM etkinlilerinin sınıftaki ögrencinin seviyesine uygun olması çok önemlidir..." şeklinde erken vazgeçmeden bahsetmiştir.

\section{STEM Ö̆̆retiminde Ö̆̆retmen}

\section{STEM Öğretimini Uygulama Siklı̆̆}

Öğretmenlerin derslerinde STEM odaklı öğretim yapma ile ilgili düşünceleri ele alındığında öğretmenlerin sınıflarında tamamının STEM öğretimi yaptığı, düşüncelerinin üç kodda toplandığı ve daha çok ara sırada yığılma olduğu görülmektedir.

\section{Tablo 10}

“Derslerinizde STEM odaklı ögrretim yapıyor musunuz? Sorusuna İlişkin Öğretmen Görüşleri. \begin{tabular}{lllllllllllll}
\hline Kodlar & Ö1 & Ö2 & Ö3 & Ö4 & Ö5 & Ö6 & Ö7 & Ö8 & Ö9 & Ö10 Ö11 Ö12 Ö13 Ö14 Ö15 Ö16 Ö17 Ö18 Ö19 Ö20
\end{tabular}

X $\mathrm{X}$
$\mathrm{X}$ $\mathrm{X}$ 


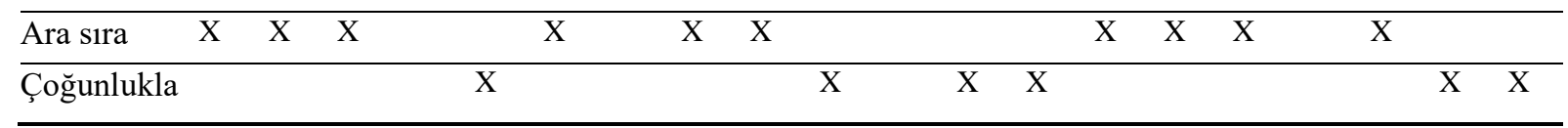

Tablo 10 incelendiğinde öğretmenlerin tamamının sınıflarında STEM öğretimi yaptığ1 görülmektedir. Fakat öğretmenlerin bir kısmı STEM odaklı öğretimi sınıflarında az uygularken, bir kısmı ara sıra ve geri kalan kısmı ise çoğunlukla uygulamaktadır. Çoğunlukla uyguladığ1 belirten Ö5 düşüncelerini “'STEM etkinlikleri tüm derslerinde uyguluyorum... Öğrencilerim bir şeyler tasarlamaktan çok hoşlanıyor." ş̧eklinde ifade etmiştir. Ara sıra uyguladığını söyleyen Ö1 ise düşüncelerini “Hafta da bir veya iki kez STEM etkinliklerini sınıfimda uygulamaya özen gösteriyorum... Özellikle fen konuları ve çevre sorunları ile ilgili konularda... MTS kullanıyorum..." şeklinde belirtirken az kullandığını ifade eden Ö4 ise “Çok fazla malzeme ve zaman gerektirmeyen konuları işlerken STEM eğitimini sınıfta uyguluyorum ... Birde karmaşa çıkmayacağını düşündüğüm konuları işlerken kullanıyorum... .” ve Ö11 ise 'STEM'i, konuyu ile STEM ögrretime uygun olduğunu düşündüm zaman STEM odaklı öğretim yapıyorum ’' şeklinde belirtmiştir.

\section{STEM Öğretimi Tasarlarken Yaşanan Kaygıları}

Öğretmenlerin ders öncesi STEM öğretim ortamı tasarlarken yaşadıkları ile ilgili fikirleri incelediğinde, bu fikirlerin beş kod altında toplandığı ve en fazla sıklığa malzeme temin edememe, STEM disiplinleri alan bilgi eksikliği ve öğretim programını yetiştirememe kodlarının sahip olduğu görülmektedir.

\section{Tablo 11}

“Ders öncesinde STEM öğretimini tasarlarken ne tür kaygılar yaşıyorsunuz?” Sorusuna İlişkin Öğretmen Görüşleri.

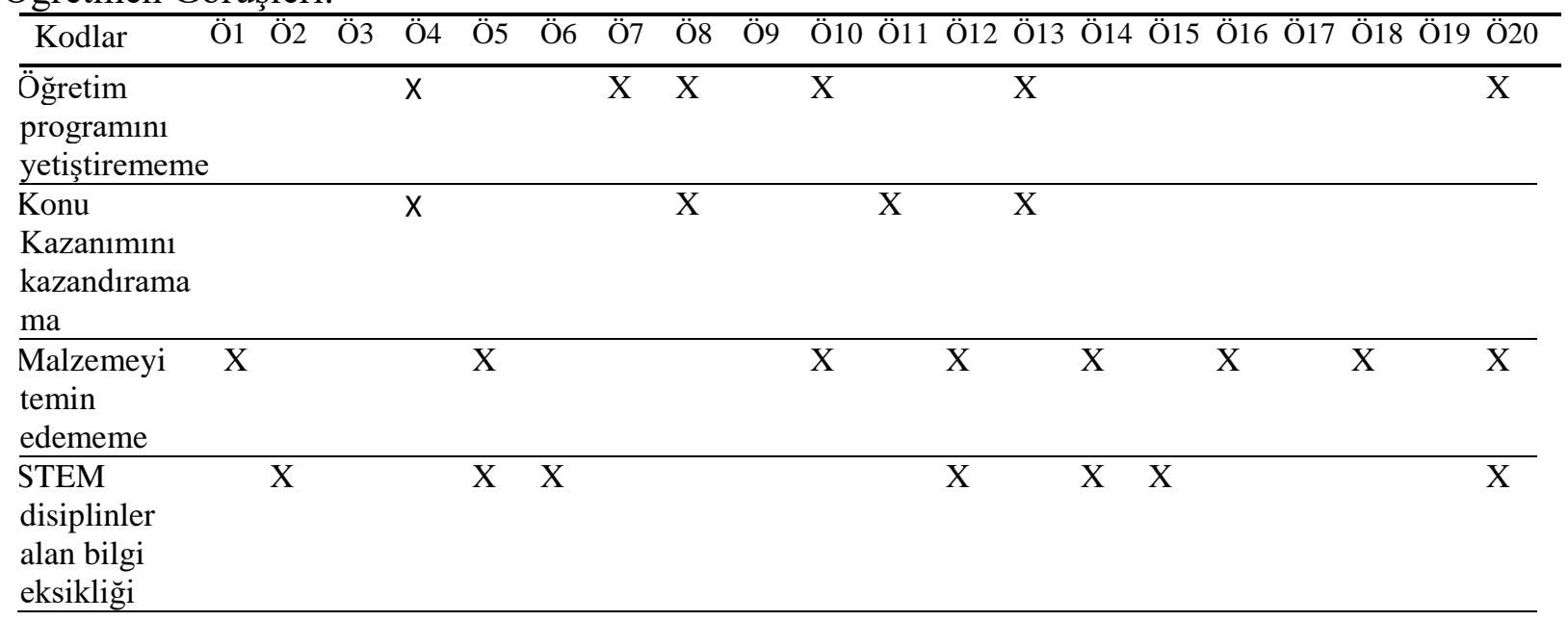


YYÜ Eğitim Fakültesi Dergisi (YYU Journal of Education Faculty), 2021;18(2)213-245, http://efdergi.yyu.edu.tr,

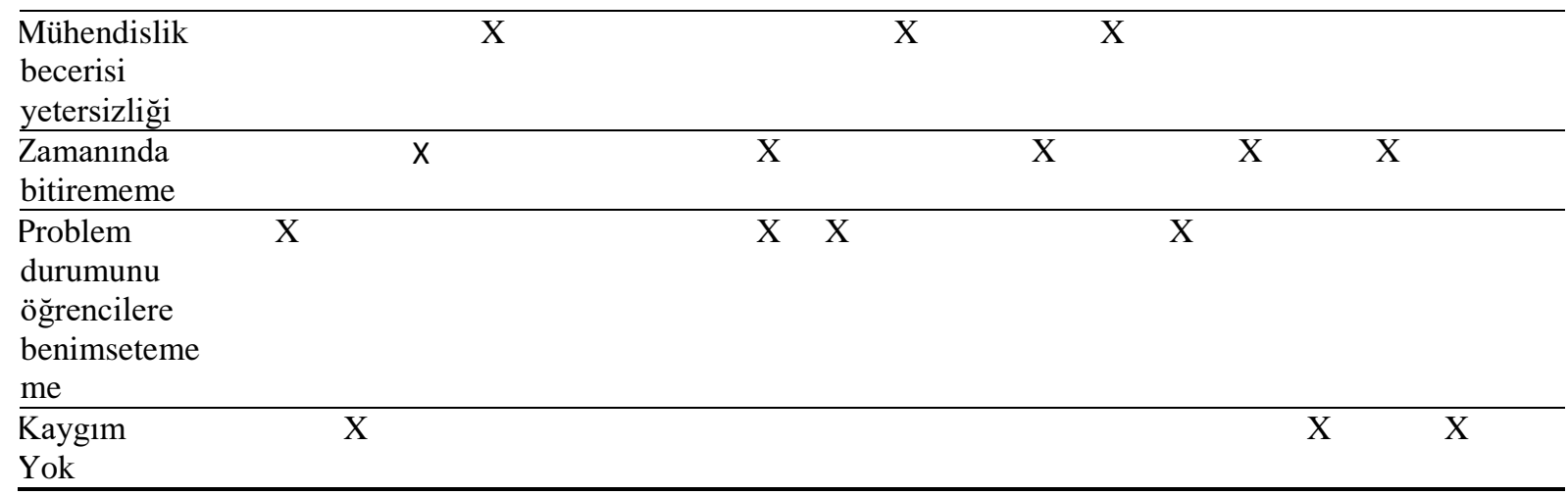

Tablo 11 incelendiğinde katılımcıların büyük bir çoğunluğu ders öncesi STEM öğretimi ortamını tasarlarken çeşitli kaygılara sahip olduğunu çok az öğretmenin sahip olmadığını görülmektedir. En çok sıklığa sahip olan malzeme temin edememe ve STEM disiplinleri alan bilgi eksikliği kaygıları ile ilgili olarak Ö14 "STEM planlarken ilk aklıma gelen soru yapacağım etkinlik için malzemeleri bulabilecek miyim... Ayrıca malzemelerinde edinmesi oldukça güç ve kullanımı için de belli bir alan bilgisi gerektirmektedir. Bunun içinde sürekli güncellenen kurslara ihtiyaç duyulmaktadır ' ' ifadesinde bulunmuştur. Bu kaygılara sahip diğer bir katılımcı Ö1 “ 'Bu tür etkinlikleri yapmayı çok istekliyim fakat basit malzeme de olsa bazen ders öncesi onu bulmanın zor olacağını dü̧̈ünerek, tasarladığım etkinliği yapmıyorum...”, düşüncesindedir. Kod sıklığı fazla olan öğretim programının yetiştirememe kaygısı ilgili olarak ise Ö8 “Kursta gördüğümüz STEM etkinlikleri müfredat içerisinde dâhil olmaması tasarladığım bu etkinliği yaparsam mevcut konuyu yetiştirilebilir miyim kaygısının ortaya çıkmasına sebep olmaktadır. Ayrıca konuyu yetiştirme kaygısı bazen etkinliği uygulamaktan vaz geçmeme neden oluyor" ifadesini kullanmıştır. Herhangi bir kaygı taşımayan öğretmen Ö3 “Etkinlik öncesi acaba bu yetişir mi kaygısı ortaya çıkıyor. Telafi edilebilir bir zaman kaybı olmaktadır. Ancak bu durum bence dezavantaj olarak kabul edilemez... Arada sıra da müzik, resim ve beden gibi dersleri kullanarak bu durumu telafi ediyorum. Çünkü bu etkinliklerde de resim yapma, çözümünü güzel anlatma ve bedenini iyi kullanarak bir şeyler yapma var..." cevabını vermiştir.

\section{STEM Öğretimi Uygularken Yaşanan Zorluklar}

Öğretmenlerin STEM öğretimini uygularken yaşanılan genel sorunlar ve güçlükler ilgili olarak ifadeleri incelediğinde, bununla ilgili olarak düşüncelerin dokuz kod altında toplandığı ve en fazla frekanslara sahip olan kodların malzeme eksikliği/kırılması, zaman sınırlaması, gürültü/karmaşa ve STEM alanlarına ait bilgi eksikliği olduğudur.

\section{Tablo 12}


“STEM öğretimi yaparken yaşadığınız sorunlar ve güçlükler nelerdir?” Sorusuna İlişkin Öğretmen Görüşleri

\begin{tabular}{|c|c|c|c|c|c|c|c|c|c|c|c|c|c|c|c|c|c|c|c|c|}
\hline Kodlar & Ö1 & Ö2 & Ö3 & Ö4 & Ö5 & Ö6 & Ö7 & Ö8 & Ö9 & Ö10 & Ö11 & Ö12 & Ö13 & Ö14 & Ö15 & Ö16 & Ö17 & Ö18 & Ö19 & Ö20 \\
\hline $\begin{array}{l}\text { Gürültü/Kar } \\
\text { maşa }\end{array}$ & $\bar{X}$ & & $\mathrm{X}$ & $\mathrm{X}$ & & & & & & & $\mathrm{X}$ & & $\bar{X}$ & & $\mathrm{X}$ & $\mathrm{X}$ & $\mathrm{X}$ & $\bar{X}$ & $\mathrm{X}$ & \\
\hline $\begin{array}{l}\text { Zaman } \\
\text { sinırlaması }\end{array}$ & & $\mathrm{X}$ & & & & $\mathrm{X}$ & & $\mathrm{X}$ & & & & $\mathrm{X}$ & & $\mathrm{X}$ & $X$ & & $\mathrm{X}$ & $\mathrm{X}$ & & $\mathrm{X}$ \\
\hline $\begin{array}{l}\text { Malzeme } \\
\text { eksikliği/ } \\
\text { kirılması }\end{array}$ & $\mathrm{X}$ & & $\mathrm{X}$ & $X$ & $\mathrm{X}$ & & & & $\mathrm{X}$ & $\mathrm{X}$ & & $\mathrm{X}$ & $\mathrm{X}$ & $\mathrm{X}$ & & $\mathrm{X}$ & & $\mathrm{X}$ & & $\mathrm{X}$ \\
\hline $\begin{array}{l}\text { Öğrenci } \\
\text { hazırbulunu } \\
\text { şluğunun } \\
\text { düşük } \\
\text { olması }\end{array}$ & & $X$ & & & $\mathrm{X}$ & & & $\mathrm{X}$ & & & & & & & $\mathrm{X}$ & $X$ & & & & \\
\hline $\begin{array}{l}\text { Planlanan } \\
\text { kazanımı } \\
\text { kazandırama } \\
\text { ma }\end{array}$ & & & & $\mathrm{X}$ & & & $\mathrm{X}$ & & & $\mathrm{X}$ & $\mathrm{X}$ & & & & & & & & & \\
\hline $\begin{array}{l}\text { Grup } \\
\text { içerisindeki } \\
\text { uyumsuzluk }\end{array}$ & & & & & & & $X$ & & $\mathrm{X}$ & & & & & & $X$ & & & & & $\mathrm{X}$ \\
\hline $\begin{array}{l}\text { Sinıf alanın } \\
\text { yetersiz } \\
\text { olması }\end{array}$ & $\mathrm{X}$ & & & $\mathrm{X}$ & & & $\mathrm{X}$ & & & & & & & $X$ & & & $X$ & & & \\
\hline $\begin{array}{l}\text { STEM } \\
\text { alanlarına } \\
\text { ait bilgi } \\
\text { eksikliği }\end{array}$ & & $X$ & $\mathrm{X}$ & $\mathrm{X}$ & & $\mathrm{X}$ & & & $\mathrm{X}$ & & & $x$ & $\mathrm{X}$ & $X$ & & & & & $x$ & $\mathrm{X}$ \\
\hline
\end{tabular}

Tablo 12 incelendiğinde katılımcıların STEM öğretimi uygularken çok çeşitli sorunlar yaşadığı görülmektedir. Ö16 yaşadığı zorlukları tanımlarken "STEM etkinlikleri esnasında kullanılan malzemeler, özellikle kodlama, robotik malzeme pahalı olduğundan her malzemeden kisıtlı sayıda yani en fazla 2 tane var, bundan dolayı uygulamada sorunlar oluyor. Öğrenciler malzemeleri stra ile kullanmaktadır. Bu seferde sirası gelmeyen ya da yapıp bitiren öğrenciler gürültü yapmakta să̆a sola giderek karmaşaya yol açmaktadır..." şeklinde ifade kullanmaktadır. Bu durumla ilgili olarak Ö12, "Genel itibariyle herhangi bir zorluk yaşamamaktayım. Tabii ki her güzel şeyin bazı sıkıntıları olmaktadır. Etkinliklerin zamanında bitmemesi gibi zorluklar yaşlyorum ama bunlar göz ardı edilmesi gereken şeyler.” şeklinde görüşünü ifade etmektedir. Ö4 ise "Materyalleri kullanırken bazen ögrenciler uygulama esnasında ilkokul öğrencisi olduğundan dolayı çocuksu tavirlar sergileyerek etkinlik amacından sapmaktadır.” ifadesini kullanarak kendi yaşadığı zorluğu tanımlamaktadır. Ö15 “Etkinlikler, öğrencilere ilk uygulandığında hazırbulunuşluk düzeyleri yetersiz olduğundan uygulamalarda zorluklar yaşamaktayım...” ve Ö2 “... STEM sinıfta uygularken öğrencimler çok çeşitli alanlardan soru soruyor bilemiyorum veya yaptı̆̆ımız STEM etkinliklerinde bir 
şeyler tasarlamak için ders dışında mühendislik, matematik, teknoloji gibi alanlara ait bilgiye ihtiyaç oluyor...’’ şeklinde kendi yaşantısından örnek vermektedir.

STEM Öğretimi için Öğretmenlere Öneriler

Öğretmenlerin STEM öğretimi yapmak isteyen öğretmenlere yönelik önerilerin neler olduğu incelediğinde, öğretmenlerin bu yöndeki önerilerinin 7 kod altında toplandığ ve en yüksek frekanslara ders öncesi hazırlık, zamanı iyi planlama ve çalışma yaprakları hazırlama kodlarının olduğu görülmektedir.

\section{Tablo 13}

"Sınıflarında STEM eğitimine dayalı öğretim yapmak isteyen öğretmenlere yönelik önerileriniz nelerdir?” sorusuna İlişkin Öğretmen Görüşleri

\begin{tabular}{|c|c|c|c|c|c|c|c|c|c|c|c|c|c|c|c|c|c|c|}
\hline Kodlar & Ö1 & Ö2 & Ö3 & Ö4 & Ö5 & Ö6 & Ö7 & Ö8 & Ö9 & Ö10 & Ö11 & Ö12 & Ö13 & Ö14 & Ö15 Ö16 & Ö17 & Ö18 Ö19 & Ö20 \\
\hline $\begin{array}{l}\text { Zamanı iyi } \\
\text { planlama }\end{array}$ & & $\bar{X}$ & $\mathrm{X}$ & & & $\mathrm{X}$ & & $\mathrm{X}$ & & $\mathrm{X}$ & & $\mathrm{X}$ & & $X$ & $\mathrm{X}$ & $\mathrm{X}$ & $\mathrm{X}$ & $\mathrm{X}$ \\
\hline $\begin{array}{l}\text { Öğretmenlerle } \\
\text { işbirliği }\end{array}$ & & & & $\mathrm{X}$ & & & $\mathrm{X}$ & & & & $\mathrm{X}$ & & $\mathrm{X}$ & $\mathrm{X}$ & & & & $\mathrm{X}$ \\
\hline $\begin{array}{l}\text { Ders öncesi } \\
\text { hazırlık }\end{array}$ & $\mathrm{X}$ & $\mathrm{X}$ & $\mathrm{X}$ & & $\mathrm{X}$ & $\mathrm{X}$ & $X$ & & & & $\mathrm{X}$ & $\mathrm{X}$ & & $X$ & $\mathrm{X}$ & & $\mathrm{X}$ & $\mathrm{X}$ \\
\hline $\begin{array}{l}\text { Tasarlama } \\
\text { becerisini } \\
\text { geliştirme }\end{array}$ & & & & & & $\mathrm{X}$ & & & & & $\mathrm{X}$ & & & & & & & \\
\hline $\begin{array}{l}\text { Çalışma } \\
\text { yaprakları } \\
\text { hazırlama }\end{array}$ & & $\mathrm{X}$ & & & $\mathrm{X}$ & & & & & & $\mathrm{X}$ & & $\mathrm{X}$ & & $\mathrm{X}$ & $\mathrm{X}$ & & $\mathrm{X}$ \\
\hline $\begin{array}{l}\text { HİE eğitim } \\
\text { alma }\end{array}$ & & & $\mathrm{X}$ & & & & & & $\mathrm{X}$ & & & & & & & & & \\
\hline $\begin{array}{l}\text { STEM etkinliği } \\
\text { geliştirme }\end{array}$ & & & & & $\mathrm{X}$ & & & $\bar{X}$ & & $\mathrm{X}$ & $\mathrm{X}$ & & & & $\mathrm{X}$ & & & \\
\hline
\end{tabular}

Tablo 13 incelendiğinde katılımcıların STEM öğretimi için diğer öğretmenlere çok çeşitli öneriler sundukları fark edilmektedir. Ders öncesi hazırlıkla ile ilgili olarak katılımcılardan Ö6 “Ders öncesi detaylı bir hazırlık birçok malzeme eksikliği, çok zaman alması veya etkinliğinin amacına ulaşmaması gibi engelleri ortadan kaldırıyor... Özellikle malzeme eksikliği.... Uygulama esnasında hemen hemen her şey yolunda gidiyor iyi bir hazırlı ve planlama ile ama her zaman ön bir hazırlık yapılamayabilir ama uyguladıkça deneyim artıyor..." şekilde düşüncelerini belirtmiştir. Ö12 ise “Ĕgitim sürekli kendini geliştiren bir alandır. Bu gelişimler doğrultusunda gerekli güncelliğin sağlanabilmesi için bu alanda öğretmenler kendini geliştirmeli kitaba bağlı kalmadan STEM etkinlikleri geliştirebilir, çünkü sınıfi ve okul çevresini sen daha iyi biliyorsun...” ifadelerini kullanmıştır. Ö13 “Etkinlikleri uygulamadan önce kesinlikle öğrenciler için etkinlik talimatlarının yer aldığı etkinlik planı geliştirilmelidir. Yoksa ögrenciler nasıl yapacaklarını, nasıl bir sırayı takip edeceklerini sürekli sorup duruyor ... Ders planı olmayınca sadece etkinlik geliştirilirsen bile sınıf kontrolü gibi sorunlar yaşanabilmektedir... Diğer branştaki öğretmenlerden yardım alınmall, bence okul olarak bu 
kurslara katılmalı ögretmenler beraber bu etkinlikleri planlamalı" cümleleriyle ders planı hazırlamaya dikkat çekmektedir.

\section{Tartışma ve Sonuç}

Elde edilen bulgular bu doğrultuda analiz edildiğinde öğretmenlerin tamamının sınıflarında disiplinler arası STEM öğretimini uyguladığı tespit edilmiştir. Alanyazında benzer bulgulara rastlamak mümkündür (Lesseig, Slavit, Nelson ve Seidel, 2016; Nadelson, Seifert, Moll ve Coats, 2012; Nadelson vd., 2013; Nadelson ve Seifert 2013; Van Haneghan, Pruet, Neal-Waltman ve Harlan, 2015; Yıldırım ve Türk, 2018). Van Haneghan ve diğerleri (2015) çalışmasında STEM eğitim çalışmalarına katılan öğretmenlerin STEM öğretiminde başarılı olduğunu ve STEM disiplinlerine yönelik farkındalıklarının arttırdığını belirtmişstir. Akaygun ve Aslan-Tutak (2016) araştırmaların da STEM eğitimi çalışmalarına katılan öğretmenlerin eğitim sonunda STEM eğitimine karşı tutumlarının, bilgi ve becerilerinin arttığını tespit etmiştir. Eroğlu ve Bektaş (2016) STEM eğitimine katılan fen bilgisi öğretmenlerinin büyük bir çoğunluğunu fen bilimlerini STEM alanlarının diğer disiplinleriyle ilişkilendirdiklerini ve fen bilimleri dersini disiplinler arası bir anlayışla ele aldıklarını tespit edilmiştir.

Derslerinde STEM öğretimi uygulayan öğretmenlerin ders konularına hangi STEM disiplin veya disiplinleri entegre ettiği incelendiğinde, katılımcı öğretmenlerin STEM öğretimlerinde kendi ders disiplinleri dışında bir veya iki disiplini derslerine entegre ettiklerini tespit edilmiştir. Fakat derslerine ikiden fazla disiplini entegre eden öğretmen sayısının az olduğu görülmüştür (Bagiati ve Evangelou 2015; El-Deghaidy vd., 2017). El-Deghaidy ve diğerleri (2017) yaptıkları çalışmada öğretmenlerde disiplinler arası öğretimin zor olduğu, ancak iki konu arasında entegrasyonun mümkün olduğu, üç veya dört STEM disiplinini bir araya getirmenin zor olduğu algısına sahip olduklarını tespit etmiştir. Çalışmada bu durumu desteklemek için Ö20’nin ' 'STEM disiplinlerinden ikisini dersine entegre eden katılımcı Ö20 “Fizik dersi STEM yaklaşımı için çok uygun bir ders, derste MTS yöntemini kullanıyorum... Problem durumunu çözüm araştırırken internet ve bilgisayar yani teknoloji kullanıyoruz... Etkinliklerde matematik de var fakat sadece işlem olarak... ', şeklindeki ifadesi gösterilebilir. Diğer taraftan katılımcı öğretmenler özellikle mühendislik ve teknoloji disiplinlerini daha çok dersleri ile bütünleştirdikleri ortaya çıkmıştır. Alanyazında yer alan araştırmalarda benzer bulgulara sahiptir (Asghar vd., 2012; Bruce-Davis vd., 2014; Dare, Ellis ve Roehrig, 2014). Dare ve diğerleri (2014) göre öğretmenlerin STEM öğretiminde daha çok mühendisliği ders konularına entegre etmelerinin nedeni, bu entegrasyonun konuyu günlük yaşam ile 
ilişkilendirdiği, öğrencilerin problem çözme becerilerini geliştirdiği ve onları geleceğe hazırlamada avantaj sağladığı yönünde düşüncelere sahip olmalarıdır. Katılımcı öğretmenlerin disiplinler arası derslerinde teknoloji entegrasyonu ile ilgili olarak ise öğretmenlerin teknolojiyi nasıl entegre edeceklerine dair net bir anlayışa sahip olmadıkları ve bunun sadece donanımsal bir entegrasyon şeklinde olduğu dikkat çekici bir diğer durum olduğu da söylenebilir (ElDeghaidy vd., 2017).

Ayrıca öğretmenler STEM çerçevesinde öğrenme ortamını oluşturmak için de büyük bir çoğunluğunun öğretim yöntemi olarak MTS yöntemini, probleme dayalı ve işbirlikçi öğrenme yöntemlerini de kullanıldığı tespit edilmiştir (Kereci ve Çınar, 2020; Lehman vd., 2014; Nadelson vd., 2013; Sandall, Sandall ve Walton, 2018; Van Haneghan vd., 2015) TosmurBayazıt ve diğerleri (2018) tarafından yürütülen çalışmada STEM eğitimi almış öğretmenlerin STEM etkinliklerinin öğrenciler için disiplinler arası ve takım çalışması için uygun ve mühendislik becerilerini pekiştirici bir öğrenme ortamı oluşturduğunu düşündüklerini tespit etmişledir. Sandall ve diğerleri (2018) STEM alanında uzman öğretmenlerle yürüttüğü çalışmada, öğretmenlerin büyük bir çoğunluğu STEM eğitiminin uygulandığı sınıflarda mühendislik tasarıma dayalı ögretim yöntemi, proje tabanlı ve probleme dayalı öğretim yöntemlerinin kullanılması gerektiğini belirtmişlerdir. National Academy of Engineering (NAE) ve National Research Council (NRC) (2014) MTS yönteminin teknoloji ve mühendislik kavramlarının öğretiminde oldukça önemli bir yöntem olduğunu, bu yöntem sayesinde bireylerin tasarım ile ilgili kavram ve ilkeleri ve problem çözümüne yönelik tasarım sürecini öğrendiğini vurgulamaktadır.

Öğretmenlerin derslerde STEM öğretiminin öğrenciler üzerine etkisi ile ilgili görüşleri inceldiğinde ise; öğretmenlerin STEM öğretiminin öğrenciler için disiplinler arası, işbirlikçi, problem dayalı ve yaratıcı bir öğrenme ortamı oluşturduğunu düşündüğü tespit edilmiştir. Yukardaki paragrafta tartışıldığı gibi öğretmenlerin STEM öğretim ortamı oluşturmak için kullandıklarını ifade ettikleri MTS, probleme dayalı öğrenme ve işbirlikçi öğrenme öğretim yöntemleri de bu öğrenme ortamlarını oluşturacağı aşikârdır. Ayrıca öğretmenler bu tür öğrenme ortamlarını yaratan STEM öğretiminin öğrencilerin 21 yy. becerileri, problem çözme ve yaratıcılık becerilerinin de gelişimine önemli katkılar sağlayacağını belirtmektedir. Benzer bulgulara alanyazında yer alan diğer araştırmalarda rastlamak mümkündür (Bölükbaşı ve Arı, 2019; Çiftçi ve Çınar, 2017; Eroğlu ve Bektaş, 2016; Tarkın-Çelikkıran ve Aydın-Günbatar, 2017; Tseng, Chang, Lou ve Chen, 2011). Tseng ve arkadaşları (2011) çalışmasında öğretmenler STEM'in öğrencilere; yaşama becerileri, 21.yüzyıl becerileri, mühendislik 
becerileri, bilimsel süreç becerileri, problem çözme becerileri, ilgi, merak, teknoloji okuryazarlığı, görsel zekâ bağlamında katkılarının olduğunu ifade etmiştir. MEB (2016) hazırladıkları raporda, STEM eğitimi uygulanan sınıflarda özgün ürünler ortaya çıktığı ve bilginin teorikten pratiğe dönüştüğü belirtilmiştir.

STEM öğretim ortamında öğrencilerin yaşadığı olumsuzluklar ile ilgili olarak ise öğretmenlerin yarısı öğrencilerin herhangi bir olumsuz durumla karşılaşmadığını belirtken diğer yarısı öğrencilerin STEM öğretim ortamında birtakım olumsuzluklarla karşılaştıklarını, özellikle pasif kalma, yetiştirememe kaygısı ve erken vazgeçme gibi olumsuzlar yaşadıkları ortaya çıkmıştır. Uğraş ve Bektaş (2016) ve Bölükbaşı ve Arı (2019) çalışmalarında benzer bulgulara sahiptir. Uğraş ve Bektaş'ın çalışmasında yer alan öğretmenler STEM öğretimi ortamında öğrencilerin yaşadığı olumsuzlukların grup içerisinde pasif kalma, zamanı verimli kullanamama ve modeli doğru bir şekilde yapamama kaygısı gibi olumsuzlukları yaşadıklarını belirtmiştir. Bölükbaşı ve Arı ise STEM öğretiminde düşük performanslı öğrencilerin STEM etkinliklerinde zorlandığını, bu da onlarda stres oluşturduğunu tespit etmiştir. STEM eğitiminde öğrenciler mühendislik tasarım sürecinde tasarımlarını ve çözümlerini geliştirmek için değişiklikler yapmak ve risk almak zorundadır. Bu geliştirme sürecinde birtakım zorluklarla mücadele eder ve hatta başarısız olurlar, bu bakımdan mücadele ve başarısızlık mühendislik tasarım sürecinin doğasında var olan değerli bileşenlerdir (Dare vd., 2014). Ayrıca araştırmacılar akademik olarak hayal kırıklığına uğramayan yüksek başarılı öğrenciler için bu durumun faydalı olduğunu düşünmektedir. Çünkü bu öğrenciler STEM öğrenmede başarılı olabilmeleri için grup çalışmasına katılmaları gerektiğini ve birçok uygulamada yaparakyaşayarak öğrenmeye ihtiyaç duyduklarını hissederler (El-Deghaidy vd., 2017; Herro ve Quigley, 2017). Ayrıca bu tür olumsuzlukların öğrencilerin yaşamasının bir diğer nedeni de öğretmenlerin öğrencilerinin STEM uygulamalarında başarılı olmasını kendilerinin akademik bir başarısı olarak görmesinden de kaynaklanabilir. Araştırmalarda öğretmenlerin, öğrencilerin STEM eğitimindeki uygulama faaliyetlerine katılımları ve öğrencilerin farklı tasarımlar üretmenleri kendilerinin akademik başarılarının önemli bir göstergesi olarak gördükleri ortaya çıkmaktadır (Bruce-Davis vd., 2014; Dare vd., 2014; Van Haneghan vd., 2015). Bu nedenle öğretmenler sınıflarında kompleks STEM etkinlikleri uygulama cabasına girebilirler, bu da öğrencilerin birtakım olumsuzluklar ve kaygılar yaşamasına sebep olabilir. Bazı araştırmalar düşük performans gösteren öğrencilerin daha az yapılandırılmış STEM problemleriyle karşılaştırdıktan daha sonra kompleks problemleri ile karşı karşıya bırakılmalarının onların başarılarını artıracağını ileri sürmektedir (Lesseig vd., 2016; Wang vd.,2011). 
Öğretmenlerin sınıflarında STEM öğretimini uygulama sıkılığı ve uygulama sırasında karşılaştıkları zorluk ve güçler incelendiğinde ise, önceden tartışıldığı gibi öğretmenler sınıflarında STEM öğretimini uygulamaktadır. Fakat uygulama sıklığı bakımından incelediğinde (Bknz, Tablo 10) ise öğretmenlerin az bir kısmı STEM öğretimini derslerinde sıklıkla uyguladığı büyük bir kısmının ise ara sıra uyguladığı ortaya çıkmıştır. Ayrıca öğretmenler ders öncesi STEM öğretim ortamı tasarlarken malzeme temin edememe, STEM disiplinleri alan bilgi eksikliği ve öğretim programını yetiştirememe kaygılarına sahip oldukları tespit edilmiştir. Bu kaygıların öğretmenlerin derslerinde STEM öğretimini uygulama sıklığını etkilediği düşünülmektedir. Bu durumu Ö1 'Bu tür etkinlikleri yapmayı çok istekliyim fakat basit malzeme de olsa bazen ders öncesi onu bulmanın zor olacă̆ını düşünerek, tasarladı̆̆ım etkinliği yapmiyorum... ” ve Ö8 “Kursta gördüğümüz STEM etkinlikleri müfredat içerisinde dâhil olmaması tasarladı̆̆ım bu etkinliği yaparsam mevcut konuyu yetiştirilebilir miyim kaygısının ortaya çıkmasına sebep olmaktadır. Ayrıca konuyu yetiştirme kaygısı bazen etkinliği uygulamaktan vaz geçmeme neden oluyor” ifadeleri de desteklemektedir. Diğer bir neden ise öğretmenlerin uygulama sırasında karşılaştıkları zorluklar olabilir. Öğretmenler sınıflarında STEM öğretimini uygularken birçok zorluk ve güçlükle karşılaştıklarını belirtirken en fazla malzeme eksikliği/kırılması, zamanında yetiştirememe ve gürültü/karmaşa gibi zorluklarla karşılaştıkları tespit edilmiştir. Benzer bulgulara alanyazında rastlamak mümkündür (Çiftçi ve Çınar, 2017; Eroğlu ve Bektaş, 2016; Kereci ve Çınar, 2020). Özellikle öğretmenlerin STEM etkinlikleri uygularken malzeme eksikliği engeli ile karşılaşmasının, öğretmenlerin STEM etkinliklerini kompleks bir model tasarlama gayretinden kaynaklandığı düşünülmektedir. Aksine çok basit malzemelerle de STEM etkinlikleri yapılabilir. Stohlman ve diğerleri (2012) STEM eğitiminde basit deney kitleri ve yalnızca tahtanın dahi kullanılabileceğini ekonomik materyallerle eğitim yapılabileceğini belirtmiştir.

Öğretmenlerin STEM öğretimi yaparken karşılaştıkları diğer bir zorluk ise haftalık ders programındaki zaman sınırlaması; birçok öğretmen STEM etkinliklerinin planlanan zamanın dışına çıktığını ve haftalık ders programında derslere ayrılan saatlerinin sınırlı olmasının bu tür çalışmaları uygulamada yetiştirememe veya başka ders saatlerine sarkma gibi soruları meydana getirdiğini belirtmiştir. STEM öğretimi tasarlamada kaygısı olmayan Ö3 kodlu öğretmenin “Etkinlik öncesi acaba bu yetişir mi kaygısı ortaya çıkıyor. Telafi edilebilir bir zaman kaybı olmaktadır. Ancak bu durum bence dezavantaj olarak kabul edilemez... Arada sıra da müzik, resim ve beden gibi dersleri kullanarak bu durumu telafi ediyorum. Çünkü bu etkinliklerde de resim yapma, çözümünü güzel anlatma ve bedenini iyi kullanarak bir şeyler yapma var..." 
ifadesi, aslında bu sorunu ve öğretmenlerin bu sorunu nasıl çözdüklerini daha net ortaya koymaktadır. Alanyazında yer alan çalışmalarda da öğretmenlerin, programdaki ders süresini sınırlamasının STEM derslerinin disiplinler arası doğasını engellediği yönünde düşüncelere sahip oldukları görülmektedir (Asghar vd., 2012; Dare vd., 2014; Lesseig vd., 2016). Ayrıca araştırmacılarda katı bir programı yapısı ve esneklik eksikliği de STEM öğretimi için bir engel olduğunu belirtmektedir (El-Deghaidy vd, 2017; Herro ve Quigley 2017; Lesseig vd., 2016). Herro ve Quigley (2017) öğretim programının hızı, öğretim sırası, programdaki konuları takip etme ve konu konu gitme gibi öğretim programın uygulama şeklindeki sınırlılıkların öğretmenlerin özgün STEM öğretimi için birden fazla disiplini entegre etme girişimlerini engellediğini ileri sürmektedir.

Diğer taraftan sınıfa hâkim olamama ya da disiplin sağlayamama gibi zorlukların alan yazında var olan çalışmalarda (Örneğin; Bakırcı ve Kulu, 2018; Capobianco, 2011; Çiftçi ve Çınar, 2017) yer almaması oldukça dikkat çekici bir durumdur. Bu kapsamda araştırma alan yazınla örtüşmemektedir. STEM etkinlik uygulamalarında sınıftaki disiplin konusunda ise araştırmacılar (Ayar, 2015; Benke, 2012) öğretmenlere gizli otorite olması gerektiğini ve öğrenciler mühendislik tasarım sürecini yürütürken bir rehber olarak otoritesinin hissettirmesi gerektiğini vurgulamaktadır. Bir diğer zorluk ise öğretmenlerin STEM disiplinlerine ait bilgilerinin eksik olmasıdır. Araştırmanın sonuçlarıyla benzer paralellikte Yıldırım ve Türk (2018) STEM uygulamalarında STEM disiplinlerinin hepsinin kullanılması gerektiğini ve öğretmenlerin bu alanlar hakkında bilgi sahibi olmaları gerektiğini ifade etmişlerdir. $\mathrm{Bu}$ eksikliğin ortaya çıkmasında en önemli faktörün öğretmenlerin hizmet-öncesi deneyimlerine bağlı olarak fen, matematik, teknoloji ve mühendislik alanlarında derslerin yeteri kadar almamasından kaynaklandığı söylenebilir. Park ve diğerleri (2016) üniversitede daha fazla fen veya matematik dersi alan öğretmenlerin STEM için gerekli olan disiplinler arası ilişki kurmalarında daha başarılı olduğunu tespit etmiştir (Bagiati ve Evangelou 2015; Bruce-Davis vd., 2014). Bu sebeple hizmet öncesi dönemde geliştirilecek STEM eğitimi derslerinde öğretmen adaylarına STEM disiplinlerine ait bilgiler kazandıracak uygulamalı derslerin yer alması oldukça önemli bir husustur (Stohlman vd.,2012).

Öğretmenlerin ders öncesi STEM öğretim ortamını tasarlarken yaşadıkları kaygılar ve bu yönde öğretim yaparken karşılaştıkları engeller doğrultusunda STEM öğretimine değer veren öğretmenlere yönelik önerileri neler olduğu incelediğinde ise, öncelikli olarak öğretmenlerin ders öncesi hazırlıklarını eksiksiz bir şekilde yapmaları, STEM etkinlikleri için gerekli olan zamanın iyi planlaması ve çalışma yaprağı hazırlama gerektiği yönünde görüş bildirdikleri 
tespit edilmiştir. Benzer bulgulara alanyazında rastlamak mümkündür (Bagiati ve Evangelou 2015; Çiftçi ve Çınar, 2017; Kereci ve Çınar, 2020; Uğraş ve Bektaş, 2016). Benzer şeklide Uğraş ve Bektaş (2016) fen bilimleri öğretmenleri ile yaptıkları çalışmalarında da benzer bulgulara ulaşılmıştır. Park ve diğerleri (2016), STEM eğitimine değer veren öğretmenlerin öğretim deneyimi arttıkça, öğretmenlerin STEM öğretimine hazır olma düzeyinin de artacağını ve bir takım zorluk ve engellerin üstesinde gelme bilgi ve becerisini kazanacaklarını savunmaktadır. Ayrıca araştırmacılar, sınıflarında öğrenci başarısındaki olumlu gelişimi fark ettikçe, öğretmenlerin STEM öğretimini uygulamaya devam etmeleri için daha çok istek duyacaklarını ileri sürmektedir.

Sonuç olarak, öğretmenlerin STEM öğretimine yönelik görüşlerinin olumlu olması hedeflenen STEM eğitiminin çıktılarının artırılması hem de öğretmenlerinin yeni yaklaşımlar yönünden kendilerini geliştirmesi bakımından önemlidir. Bu nedenle öğretmenlerinin STEM öğretimi konusunda görüşlerinin alınması, diğer öğretmenler tarafından STEM öğretimini daha etkili bir şekilde uygulanması açsısından, STEM eğitimine ve öğrenimine 1şı tutacağ düşülmektedir.

\section{Öneriler}

Öğretmenlerin, STEM eğitimi uzmanları ile oluşturduğu iş birliği kültürü STEM programlarının uygulanabilirliğini önemli derece artırabilir (Asghar vd., 2012; Bruce-Davis vd., 2014; Herro ve Quigley 2017; Lehman vd., 2014; Stohlmann vd., 2012; Wang vd., 2011). Yapılan araştırmalarda öğretmenlerin, STEM dersleri için gerekli olan başarının ve disiplinler arası öğretimin anahtarının bu iş birliği kültürünün olduğunu belirttikleri görülmektedir. (Herro ve Quigley 2017; Stohlmann vd., 2012). Lehman ve diğerleri (2014) yaptığı çalışmada öğretmenlerin STEM alanındaki uzman öğretim üyeleriyle ve uzman öğretmenlerle yaptıkları iş birliğinin onların STEM öğretimlerini çok daha verimli kıldığını tespit etmiştir. Ayrıca Lehman ve diğerleri, sağlanan bu desteklerin öğretmenlerin risk alma konusunda kendilerini rahat hissetmelerine ve kendi branşları dışındaki STEM kavramlarını daha derinlemesine incelemelerine yardımcı olduğunu belirtmektedir.

Öğretmenlerin, sınıflarında kullanabilecekleri çeşitli yardımcı öğretim materyalleri desteklenmelerinin de onların STEM öğretim etkinliklerini tasarlarken ve uygularken oldukça fayda sağlayacağı düşünülmektedir. Öğretmenler, bu tür sağlanacak bir destek kendilerine olan inançlarını veya öz yeterliklerini artırabilir (Lehman vd., 2014; Van Haneghan vd., 2015). Ayrıca bazı öğretmenler öğretim programında yer alan STEM etkinliklerini çeşitli nedenlerden dolayı uygulamak istemeyebilir (Asghar vd., 2012; Herro ve Quigley 2017). Bu durumda 
öğretmenlere yardımcı öğretim materyallerinin sağlanması oldukça faydalı olacaktır. Örnek olarak, Asghar ve diğerleri (2012) ve Wang ve diğerleri (2011) yaptıkları çalışmalarda öğretmenlerin farklı alanları derslerine entegre etmek için gerekli olan STEM problemlerini geliştirmede zorlandıklarını ve öğretmenlerin STEM disiplinleri ve öğretim programları üzerine inşa edilmiş STEM problemlerinin yer aldığı öğretim materyallerine ihtiyaç duyduklarını tespit etmiştir. Wendell'e (2008) göre sınıflarda günlük yaşam problemleri üzerinden dersin işlenmesi öğrencilerin probleme yönelik birden fazla çözüm üretmelerini ve birçok disiplin çözüme sürecine entegrasyonu gerçekleştirir. Bu durumu destekleyici olarak Sandall ve diğerleri (2018) ise birden fazla STEM disiplininin birbirine entegre edilmesi ile oluşan bir öğretim sürecinin öğrencilerin farklı disiplinler hakkında bilgi sahibi olmasını sağlayacağını savunmaktadır.

\section{Araştırmanın Sınırlılıkları}

$\mathrm{Bu}$ çalışma STEM HİE almış olan farklı branşlardaki 20 fen öğretmeni ile gerçekleştirilmiştir. Fakat öğretmenlerin branş, cinsiyet, deneyim y1lı gibi farklı demografik özellikleri dikkate alınarak elde edilen veriler analiz edilmemiş ve genel bir değerlendirme yapılmıştır. Bu da araştırmanın bir sınırlılığı olarak gösterilebilir. Bundan sonra yapılabilecek araştırmalarda bu demografik özelliklere göre öğretmenlerin STEM öğretimi hakkındaki düşüncelerinin farklılık gösterip göstermediğine bakılabilir. Ayrıca öğretmenlerin sınıflarında yaptıkları öğretimlerin gözlemlendiği uzun süreli bir incelemenin söz konusu olduğu bir boylamsal bir çalışma planlanabilir. Böylelikle daha zengin ve derinlemesine verilerin elde edildiği farklı bir nitel çalışma sayesinde alanyazına daha çok katkı sağlayacağı söylenebilir.

\section{Makalenin Bilimdeki Konumu}

Öğretmen Eğitimi, STEM Eğitimi

\section{Makalenin Bilimdeki Özgünlüğü}

STEM HİE almış öğretmenlerin konuya bakış açılarının, STEM öğretiminde elde ettikleri öğrenme çıktıklarının ve uygulamada karşılaştıkları sorunların ve güçlüklerin bilinmesi diğer öğretmenler için STEM eğitimine karşı bir farkındalık ve uygulama bakımından önemli düzeyde motivasyon oluşturabileceği düşünülmektedir. Bu bağlamda bu çalışmada STEM eğitimi almış öğretmenlerin STEM öğretimleri hakkında görüşlerini, uygulamalar sırasında yaşadıkları sorunları ve çözüm önerileri incelenmiştir. 


\section{KAYNAKLAR}

Akaygun, S., ve Aslan Tutak, F. (2016). STEM images revealing stem conceptions of pre service chemistry and mathematics teachers. International Journal of Education in Mathematics, Science and Technology, 4(1), 56- 71.

Altan, E. B., ve Ercan, S. (2016). STEM education program for science teachers: perceptions and competencies, Journal of Turkish Science Education, 13(Special Issue), 103-117.

Asghar, A., Ellington, R., Rice, E., Johnson, F., ve Prime, G. M. (2012). Supporting STEM education in secondary science contexts. The Interdisciplinary Journal of Problem-based Learning, 6(2), 85-125. https://doi.org/10.7771/1541-5015.1349.

Aydeniz, M. (2017). Eğitim sistemimiz ve 21. yüzyıl hayalimiz: 2045 hedeflerine ilerlerken, Türkiye için STEM odaklı ekonomik bir yol haritası. University of Tennessee, Knoxville (Erişim Tarihi: 20/10/2019). https://trace.tennessee.edu/cgi/viewcontent.cgi?referer=https://www.google.com/\&https redir=1\&article=1019\&context=utk_theopubs'den alınmıştır.

Bagiati, A., ve Evangelou, D. (2015). Engineering curriculum in the preschool classroom: the teacher's experience. European Early Childhood Education Research Journal, 23(1), 112-128. https://doi.org/10.1080/1350293X.2014. 991099

Bakırcı, H. ve Kutlu, E. (2018). Fen bilimleri öğretmenlerinin FeTeMM yaklaşımı hakkındaki görüşlerinin belirlenmesi. Türk Bilgisayar ve Matematik Eğitimi Dergisi, 9(2), 367-389.

Bölükbaşı, G., ve Arı, A. (2019). Fen Bilimleri Öğretmenlerinin FeTeMM Eğitimi ve Etkinliklerine Yönelik Görüşleri. Akademik Platform, 2(1), 47-56. https://doi.org/10.33793/acperpro.02.01.11

Bruce-Davis, M. N., Gubbins, E. J., Gilson, C. M., Villanueva, M., Foreman, J. L., ve Rubenstein, L. D. (2014). STEM high school administrators', teachers', and students' perceptions of curricular and instructional strategies and practices. Journal of Advanced Academics, 25(3), 272-306. https://doi.org/10.1177/ $1932202 X 14527952$.

Capobianco, B. M. (2011). Exploring a science teacher's uncertainty with integrating engineering design: an action research study. Journal of Science Teacher Education, 22, 645-660.

Çepni, S. (2007). Araştırma ve proje çalışmalarına giriş. Trabzon: Celepler Matbaacılık. 
Çınar, S., Pırasa, N., ve Sadoğlu, G. (2016). Views of science and mathematics pre-service teachers regarding STEM. Universal Journal of Educational Research, 4(6), 1479-1487. DOI: 10.13189/ujer.2016.040628

Çınar, S., Pırasa, N., Uzun, N., ve Erenler, S. (2016). The effect of STEM education on pre-service science teachers' perception of interdisciplinary education. Journal of Turkish Science Education, 13, 118-142. DOİ: 10.12973/tused.10175a

Çınar S., ve Kereci, N. (2020). Sınıf öğretmenlerinin mühendislik tasarım uygulamalarının fen bilimleri öğretimine entegrasyonu hakkındaki görüşleri: Ordu örneği, International Journal of Innovative Approaches in Education, 4(2), 26-45. https://doi.org/10.29329/ijiape.2020.261.1

Çiftçi, M., ve Çınar, S. (2017, Nisan). Fen bilgisi ögrretmenlerinin STEM eğitiminin fen bilimleri dersine entegrasyonu hakkındaki görüşleri. Sözel bildiri, VII. Uluslararası Eğitimde Araştırmalar Kongresi, Çanakkale.

Dare, E. A., Ellis, J. A., ve Roehrig, G. H. (2014). Driven by beliefs: understanding challenges physical science teachers face when integrating engineering and physics. Journal of Pre-College Engineering Education Research, 4(2), 47-61. https://doi.org/10.7771/2157-9288.1098

El-Deghaidy, H., Mansour, N., Alzaghibi, M., ve Alhammad, K. (2017). Context of STEM integration in schools: views from in-service science teachers. EURASIA Journal of Mathematics, Science, and Technology Education, 13(6), 2459-2484. https://doi.org/10.12973/eurasia.2017.01235a

Eroğlu, S., ve Bektaş, O. (2016). STEM eğitimi almış fen bilimleri öğretmenlerinin STEM temelli ders etkinlikleri hakkındaki görüşleri. Eğitimde Nitel Araştırmalar Dergisi 4(3), 43-67.

Gökçe, T. A., ve Yıldırım, D. (2019, Mayıs). Öğretmenlerin STEM ĕ̌̆itiminde yaşadı̆̆ sorunlar ve çözümleri. Sözel bildiri, 14. Uluslararası Eğitim Yönetimi Kongresi, İzmir.

Herro, D., ve Quigley, C. (2017). Exploring teachers' perceptions of STEAM teaching through professional development: implications for teacher educators. Professional Development in Education, 43, 416-438. https://doi.org/10.1080/ 19415257.2016.1205507 
Lehman, J. D., Kim, W., ve Harris, C. (2014). Collaborations in a community of practice working to integrate engineering design in elementary science education. Journal of STEM Education: Innovations and Research, 15(3), 21-28.

Lesseig, K., Slavit, D., Nelson, T. H., ve Seidel, R. A. (2016). Supporting middle school teachers' implementation of STEM design challenges. School Science and Mathematics, 116(4), 177-188. https://doi.org/10.1111/ssm.12172

Margot, K. C., ve Kettler, T. (2019). Teachers' perception of STEM integration and education: a systematic literatüre review International Journal of STEM Education, 6(2),2-16. https://doi.org/10.1186/s40594-018-0151-2

MEB(2016). STEM Eğitim Raporu (Erişim Tarihi: 10.11.2019). https://yegitek.meb.gov.tr/STEM_Egitimi_Raporu.pdf‘den alınmıştır.

MEB (2017). STEM Eğitimi Öğretmen El Kitabı (Erişim Tarihi: 10.05.2018). http://scientix.meb.gov.tr/images/upload/Event_35/Gallery/STEM\%20E\%C4\%9Fitimi \%20 \%C3\%96\%C4\%9Fretmen\%20El\%20Kitab\%C4\%B1. Pdf'den alınmıştır.

MEB(2018). 2023 Vizyon Belgesi (Erişim Tarihi: 11.05.2018). http://2023vizyonu.meb.gov.tr/'den alınmıştır.

Miles, B. M., Huberman A. M. (1994). Qualitative data analysis: An expanded source book. California, USA: Sage Publications.

Nadelson, L. S., Seifert, A., Moll, A. J., ve Coats, B. (2012). I-STEM summer institute: an integrated approach to teacher professional development in STEM. Journal of STEM Education: Innovations and Research, 13(2), 69-83. Retrieved

Nadelson, L. S., Callahan, J., Pyke, P., Hay, A., Dance, M., ve Pfiester, J. (2013). Teacher STEM perception and preparation: inquiry-based STEM Professional development for elementary teachers. The Journal of Educational Research, 106(2), 157-168. https://doi.org/10.1080/00220671.2012.667014.

Nadelson, L. S., ve Seifert, A. (2013). Perceptions, engagement, and practices of teachers seeking professional development in place-based integrated STEM. Teacher Education and Practice, 26(2), 242-265.

Nathan, M. J., Atwood, A. K., Prevost, A., Phelps, L. A., ve Tran, N. A. (2011). How professional development in project lead the way changes high school stem teachers' beliefs about engineering education. Journal of Pre-College Engineering Education Research (J-PEER), 1(1), 15-29. https://doi.org/10.7771/2157-9288.1027 
National Academy of Engineering (NAE) and National Research Council (NRC). (2014). STEM integration in K-12 education: status, prospects, and an agenda for research. In M. Honey, G. Pearson, \& H. Schweingruber (Eds.), Committee on K-12 engineering education. Washington, DC: National Academies Press.

Park, H., Byun, S., Sim, J., Han, H., ve Baek, Y. S. (2016). Teachers’ perceptions and practices of STEAM education in South Korea. Eurasia Journal of Mathematics, Science, \& Technology Education, 12(7), 1739-1753. https://doi.org/10.12973/ Eurasia.2016.1531a.

Sandall, B. K., Sandall, D. L., ve Walton, A. L. J. (2018). Educators' perceptions of integrated STEM: A Phenomenological Study, Journal of STEM Teacher Education, 53(1), 27-42. DOI: doi.org/10.30707/JSTE53.1Sandall

Stohlmann, M., Moore, T. J., ve Roehrig, G. H. (2012). Considerations for teaching integrated STEM education. Journal of Pre-College Engineering Education Research, 2(1), 28-34. https://doi.org/10.5703/1288284314653

Tarkın-Çelikkıran, A., ve Aydın-Günbatar, S. (2017). Kimya öğretmen adaylarının FeTeMM uygulamaları hakkındaki görüşlerinin incelenmesi. Yüzüncü Yll Üniversitesi Eğitim Fakültesi Dergisi, 14(1), 1624-1656.

Timur, S., Timur, B., ve Cetin, N.I. (2019). Effects of STEM based activities on in-service teachers’ views. Educational Policy Analysis and Strategic Research, 14(4), 102-113. doi: 10.29329/epasr.2019.220.6

Tseng K. H., Chang, C. C., Lou, S. J., ve Chen, W. P. (2011). Attitudes towards Science, Technology, Engineering and Mathematics (STEM) in a project-based learning (PjBL) environment. International Journal of Technology and Design. 23, 87-102. https://doi.org/10.1007/s10798-011-9160-x

Türkiye Sanayi ve İş adamları Derneği [TÜSİAD] ve PwC (2017). 2023'e doğru Türkiye'de STEM gereksinimi (Erişim Tarihi: 01.01.2018). http://www.tusiadstem.org/images/raporlar/2017/STEM-Raporu-V7.pdf'den alınmıştır.

Tosmur-Bayazıt, N., Akaygün S., Demir K., ve Aslan-Tutak, F. (2018). Bir STEM öğretmen eğitimi örneği: Yenebilir arabalar etkinliğinin öğretmen eğitimi açısından incelenmesi. Fen Bilimleri Öğretim Dergisi, 6(2), 213-232. https://dergi.fead.org.tr/wpcontent/uploads/5.pdf

Van Haneghan, J. P., Pruet, S. A., Neal-Waltman, R., ve Harlan, J. M. (2015). Teacher beliefs about motivating and teaching students to carry out engineering 
design challenges: some initial data. Journal of Pre-College Engineering Education Research, 5(2), 1-9. https://doi.org/10.7771/2157-9288.1097.

Wang, H. H., Moore, T. J., Roehrig, G. H., ve Park, M. S. (2011). STEM integration: teacher perceptions and practice. Journal of Pre-College Engineering Education Research, 1(2), 1-13. https://doi.org/10.5703/1288284314636

Wendell, K. B. 2008. The theoretical and empirical basis for design-based science instruction for children. Qualifying Paper, Tufts University.

Yıldırım, A., ve Şimşek, H. (2011). Sosyal bilimlerde nitel araştırma yöntemleri. Ankara: Seçkin Yayınları.

Yıldırım, B., ve Türk, C. (2018). Sınıf öğretmeni adaylarının STEM eğitimine yönelik görüşleri: Uygulamalı bir çalışma. Trakya Eğitim Dergisi, 8(2), 195-213.

\section{Summary}

\section{Statement of Problem}

Pre-service and in-service training activities are critical for the successful implementation of STEM education. In this sense, various researches clarified that teachers' belief, motivation, and awareness are seriously important for effective educational reforms (Nathan, Atwood, Prevost, Phelps, and Tran, 2011). Margot and Keller (2019) argue that the value of teachers affects their desire to both involving in and applying STEM teaching. Park et. al., (2016) argue that the teaching experience in STEM education increases the level of readiness and that not only improves their further knowledge and skills but also overcomes some difficulties and obstacles. Teachers who value STEM education would be motivated to continue applying STEM teaching when they experience their students' achievement in their classrooms. On the other hand, it can be stated that organizing STEM ISE [In-Service Training] training courses for all kinds of teachers is very difficult due to the fact that there are various reasons in particular cost, time, and qualified workforce.

In the case of STEM education to be successful in schools, it ought to make various efforts to improve teachers' perceptions (Gökçe and Y1ldırım, 2019). This effort can make a significant contribution to teachers' successful STEM teaching under the guidance of teaching materials available in their classrooms. In this context, it is very important to know the perspectives of teachers who practice STEM teaching in their classrooms, their learning outcomes in STEM teaching, and the obstacles and suggestions they encounter in practice. Studies clarified that the culture of collaboration with experts in STEM education would increase the applicability of STEM programs (Asghar et. al., 2012; Bruce-Davis et. al., 2014; 
Herro and Quigley 2017; Lehman et. al., 2014; Stohlmann et. al., 2012; Wang et. al., 2011). In this sense, it is very important for teachers who teach STEM in their classes to share their thoughts about their knowledge and experiences. Therefore, the aim of this study is to reveal the views of STEM-educated teachers about STEM education, in particular the problems they experienced during the applications and their solution suggestions.

\section{Method}

This study was conducted with STEM-educated teachers who are working in Bayburt in the fall semester of 2019-2020 academic years. The phenomenographic study which is one of the qualitative research methods was used in the study. The purpose of phenomenographic studies conducted in the field of education is to define the different views of individuals, particularly their experiencing, interpreting, understanding, and conceptualizing a particular aspect of phenomenon (Çepni, 2007). In addition, such studies describe a phenomenon acquired by individuals, possible different concepts with simple logic, and are explained as learning and teaching situations that appear as a link between the individual and the experience. Within the framework of this theoretical basis, the phenomenographic study was preferred to reveal teachers' views on STEM-focused teaching based on their experiences of interpretation and understanding of STEM education.

\section{Discussion and Conclusion}

It has been determined that all teachers apply STEM teaching in their classrooms. It was also determined that participating teachers integrated one or two disciplines other than their own subject disciplines into their lessons. However, it was observed that the number of teachers who integrated more than two disciplines into their lessons was low. On the other hand, it has been revealed that participating teachers mostly integrate engineering and technology disciplines. It has been determined that most of the teachers use MTS (Engineering Design Process) as a teaching method and problem-based and collaborative learning methods in order to create a learning environment within the framework of STEM.

When examining the views of teachers about the effect of STEM-focused teaching on students; It has been determined that teachers stated that STEM-focused teaching creates an interdisciplinary, collaborative, problem-based, and creative learning environment for students. In addition, teachers stated that STEM teaching, which has such a teaching environment, would make significant contributions to the development of 21st-century skills, problem-solving, and creativity. 
When examining the teachers' suggestions for the value of STEM teaching in line with their anxieties while designing the pre-lesson STEM teaching environment and the obstacles they face while teaching in this direction. First of all, teachers should make complete pre-lesson preparations, plan the time required for STEM activities and work accordingly. It was determined that the leaf of opinion expression should be prepared. Park et al. (2016) argue that the teaching experience of teachers who value STEM education increases their readiness for STEM teaching that leads not only to the improvement of knowledge and skills but also overcome some difficulties and obstacles. In addition, researchers suggest that when they begin to experience student success in their classrooms, teachers would be more willing to continue practicing STEM teaching.

\section{Recommendations}

It can be stated that teachers believe that the culture of collaboration created with STEM education experts would increase the applicability of STEM programs (Asghar et al., 2012). Teachers consider this collaborative culture to be the key to success and interdisciplinary teaching required for STEM lessons. (Herro and Quigley 2017; Stohlmann et. al., 2012). Lehman et. al., (2014) found in their study that the collaboration of teachers with expert faculty members and expert teachers in the field of STEM made their STEM teaching much more efficient. In addition, the researchers stated that these supports helped teachers to feel comfortable about taking risks and to examine the STEM concepts outside their branches more in-depth. On the other hand, it is thought that supporting supportive teaching materials that teachers can use in their classrooms would be very beneficial while designing and implementing STEM teaching activities. Supporting teachers can increase their self-esteem or self-efficacy (Lehman et. al., 2014; Van Haneghan et. al., 2015). 